\title{
Major and trace element geochemistry of the Platreef on the farm Townlands, northern Bushveld Complex
}

\author{
Tawanda D. Manyeruke and Wolfgang D. Maier \\ Centre for Research on Magmatic Ore Deposits (CERMOD), \\ Geology Department, University of Pretoria, Pretoria 0002, South Africa \\ e-mail: s22377523@tuks.co.za and wdmaier@scientia.up.ac.za \\ Sarah-Jane Barnes \\ Université du Québec à Chicoutimi, 555 Boulevard Université, Chicoutimi, Québec, G7H 2B1 \\ e-mail: sjbarnes@uquc.ca \\ (C) 2005 Geological Society of South Africa
}

\begin{abstract}
The Platreef is a platinum group elements and base metal enriched mafic/ultramafic layer situated along the base of the northern limb of the Bushveld Complex. The present study contains a detailed petrographic and geochemical investigation of a borehole core intersection through the Platreef on the farm Townlands. At this locality, the Platreef rests on metasedimentary rocks of the Silverton Formation of the Transvaal Supergroup, and is comprised of three medium-grained units of gabbronorite/feldspathic pyroxenite that are separated by hornfels interlayers. We refer to the three platiniferous layers as the Lower, Middle and Upper Platreef. The Middle Platreef is the main mineralised layer, with total PGE contents up to $4 \mathrm{ppm}$. The Lower and Upper Platreefs are less well mineralised (up to $1.5 \mathrm{ppm}$ ).

Trace element and S-isotope data show compositional breaks between the different platiniferous layers suggesting that they represent distinct sill-like intrusions of pyroxene and sulphide enriched crystal mushes. The study also reveals a reversed differentiation trend of more primitive rocks towards the top of the succession. For example, orthopyroxene shows an increase in $\mathrm{Cr}_{2} \mathrm{O}_{3}$ from 0.07 to 0.37 weight \% with height and the whole rock concentration of incompatible trace elements such as $\mathrm{Y}$ and $\mathrm{Zr}$ decreases. This pattern is interpreted to reflect enhanced crustal contamination of the lower Platreef layers.

All three Platreef layers are enriched in heavy S ( $\delta^{3+} \mathrm{S}$ of 2.6 to $9.1 \%$ ) indicating addition of crustal sulphur, and they have elevated $\mathrm{K}, \mathrm{Ca}, \mathrm{Zr}$ and $\mathrm{Y}$ contents and high $\mathrm{Zr} / \mathrm{Y}$ ratio relative to Critical Zone rocks from elsewhere in the Bushveld Complex, suggesting a model of crustal contamination in ore formation.

Well defined correlations between the concentrations of the individual PGE, and between the PGE and S suggest that the concentration of the PGE was controlled by segregating sulphide melt. Alteration of the rocks, possibly due to infiltration by fluids derived from the floor rocks, caused localized redistribution of $\mathrm{Cu}, \mathrm{S}$ and, to a lesser degree, the PGE. However, alteration, sulphur and metal mobility was apparently much less pronounced at Townlands than at other Platreef localities further to the north, notably at Sandsloot mine where the PGE are largely hosted by PGM (Armitage et al., 2002). We suggest that this is due to more pronounced devolatisation of the dolomites relative to the shales, implying that the nature of the floor rocks plays an important role in ore formation.
\end{abstract}

\section{Introduction}

The Platreef is a platinum group element (PGE) and base metal enriched mafic- ultramafic layer situated along the base of the northern limb of the Bushveld Complex (Figure 1). It represents an important resource of PGE, estimated to contain 6581 tonnes of PGE to a depth of $1200 \mathrm{~m}$ (Vermaak, 1995), which is only in its early stages of exploitation. In addition to the northern limb, basal PGE mineralisation of a broadly similar type to that found in the Platreef has recently been described from the Mineral Range (Sharpe et al., 2002). In the remainder of the Complex, basal PGE mineralisation appears to be absent. Past workers have proposed that this is due to the fact that the floor rocks to most of the eastern and western limbs of the Bushveld Complex are constituted by relatively refractory quartzites. In contrast, in the northern limb, the floor rocks show more lithological variation, including shale, ironstone, dolomite, and granite gneiss in addition to quartzite. Some of these lithologies, notably the dolomites, are believed to be more reactive when in contact with magma (e.g. de Waal, 1977). The assimilation of country rock material by basaltic magma is generally thought to be important in the formation of magmatic sulphides (Naldrett, 1989). However, the precise mechanism that may have triggered the sulphide segregation in the Platreef remains unclear. For example, Haughton et al. (1974) and de Waal (1977) proposed that devolatisation of the dolomite may increase the $O$ fugacity of the magma, thereby decreasing the activity of $\mathrm{Fe}^{2+}$ and the S solubility. Alternatively, sulphide melt segregation could have been triggered by assimilation of $\mathrm{S}$ from the floor rocks, a model that is supported by relatively high values of $\delta^{34} \mathrm{~S}$ in the mineralised rocks (White, 1994). Some authors (Lee, 1996) proposed that the Platreef sulphides segregated in a staging chamber at depth and were entrained by the ascending silicate magma. 


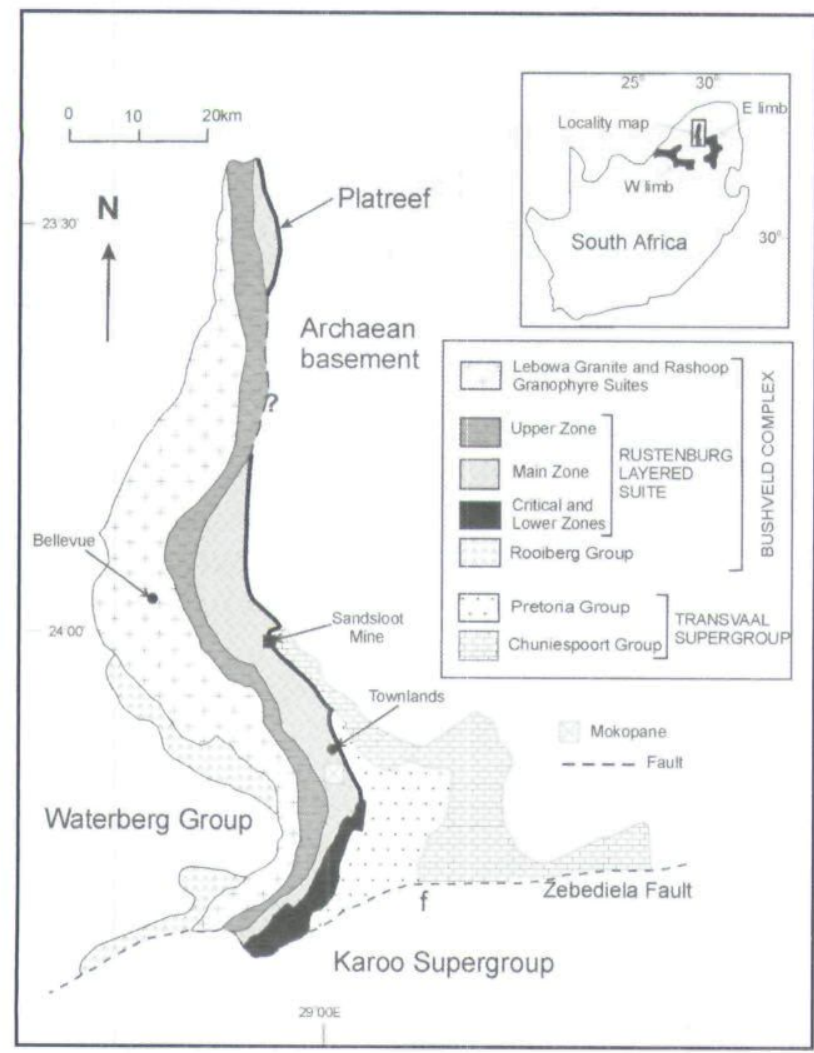

Figure 1. Geological map of the Porgietersrus limb of the Bushveld Complex. Insert shows the outcrop of the Rustenburg Layered Suite in Southern Africa (modified after Harris and Chaumba, 2001).

One of the main problems in constraining the mechanism of mineralization is that there have been few quantitative studies of trace elements and, in particular, noble metal concentrations in the Platreef rocks. The most comprehensive description of the mineralization so far has been published by Viljoen and Schürmann (1998). Maier (2002) presented Pt, Pd, Cu and $\mathrm{Ni}$ contents of the Platreef on the farm Townlands. Armitage et al. (2002) published more complete noble metal data from 13 Platreef samples at Sandsloot, some $30 \mathrm{~km}$ to the north of Mokopane. The scarcity of data make it difficult to judge whether there is any systematic regional variation in metal tenors and whether such variation, if present, can be correlated to lithological and chemical variation of the intrusion and the floor rocks. The present study was initiated to expand the available database on the Platreef, and thereby help to constrain the genesis of the mineralization.

\section{General geology}

The geology of the Platreef has been described by several previous authors (Buchanan et al., 1981; Cawthorn et al., 1985; Barton et al., 1986; White, 1994; Harris and Chaumba, 2001). The Platreef consists of an up to $400 \mathrm{~m}$ thick package of texturally heterogeneous pyroxenites, norites and gabbros, containing numerous xenoliths of calcsilicate and hornfels derived from the dolomitic and pelitic floor rocks. Other floor lithologies (e.g., quartzite, $\mathrm{Fe}$ - formation and granite) seem to be poorly represented amongst the xenolith population. The reef is overlain by a thick (up to $2000 \mathrm{~m}$ ) package of gabbro, magnetite gabbro and diorite belonging to the Main and Upper Zones of the Rustenburg Layered Suite. Platreef rocks have been observed from $c a .25 \mathrm{~km}$ south of the town of Mokopane to the northernmost parts of the northern limb, i.e. along a strike length of ca. $100 \mathrm{~km}$ (White, 1994). However, the nature and grade of the mineralisation appears to be laterally variable and it remains unclear whether the reef is developed continuously. Viljoen and Schürmann (1998) and White (1994) report that the well mineralised sectors of the Platreef extend for about $35 \mathrm{~km}$ from the farm Townlands in the south to the farm Drenthe in the north. Recent reports from various exploration companies (e.g., www.panpaladium.au) suggest that the Platreef is developed along most of the base of the northern limb of the Complex, albeit in variable thickness. Part of the variability of the Platreef mineralisation may be related to the fact that in the northern limb, the Bushveld has a transgressive relationship with the Transvaal Supergroup. Thus, to the south of Mokopane, the reef overlies the Magaliesberg quartzite Formation, but towards the north, it rests on progressively lower portions of the Pretoria Group until it abuts the Archaean granite-gneiss basement (Figure 1).

Wagner (1929) and White (1994) interpreted the Platreef as an equivalent to the Merensky reef, partly based on the presence of sulphide mineralisation associated with coarse-grained (pegmatoidal) pyroxenites in both cases. However, there are several important differences between the Platreef and the Merensky reef as exposed in the western and eastern lobes of the Complex. Firstly, the Merensky reef tends to occur within the layered sequence, in many instances some $2 \mathrm{~km}$ above the floor of the Bushveld Complex, whereas the Platreef directly overlies the floor of the complex or is separated from the latter by a few 10 's of meters. Secondly, the mineralized interval is much thicker in the Platreef than in the Merensky reef (up to $400 \mathrm{~m}$ versus $c a .1 \mathrm{~m}$ ). Thirdly, there are important compositional differences between the two layers, e.g. a relatively higher crustal component and mostly lower metal contents and tenors in the Platreef (e.g. Buchanan et al. 1981; Manyeruke, 2003) relative to the Merensky reef (Barnes and Maier, 2002). For example, the Platreef on Townlands has $0.55 \mathrm{ppm}$ Pt and Pd over $c a .70 \mathrm{~m}$, and $\mathrm{Pt}$ and $\mathrm{Pd}$ tenors of the sulphides between 10 and $50 \mathrm{ppm}$. At Sandsloot, grades locally reach $>10 \mathrm{ppm}$, and PGE tenors can be in excess of 100ppm (Armitage et al., 2002). The Merensky reef has PGE and Au grades of 4 to 6 ppm over $c a .1 \mathrm{~m}$ (SA Mining, 2004) and metal tenors of several $100 \mathrm{ppm}$ in the sulphides. (Barnes and Maier, 2002). Fourthly, the Platreef is lithologically more variable, and contains abundant floor rock xenoliths.

\section{Geology of the Platreef on Townlands Nomenclature}

The following description of the Platreef on the farm 


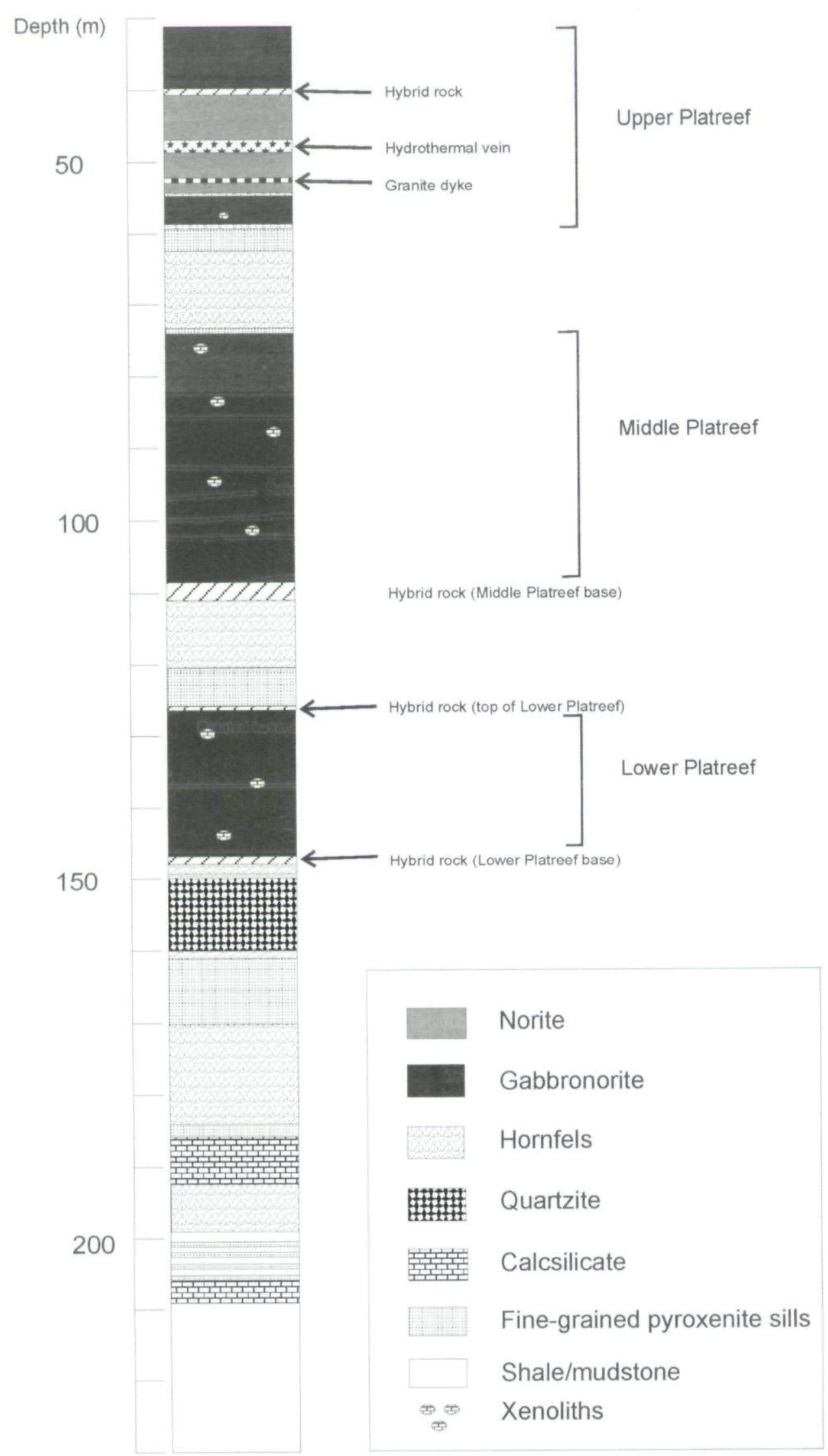

Figure 2. Generalised profile of borehole TL01-3 on the farm Townlands. 
Townlands is based on a $230 \mathrm{~m}$ borehole core (TL01-3) that intersects a significant portion of the reef and some of the floor rocks (Figure 2).

The Platreef consists of three packages of mediumgrained gabbronorite and, locally, feldspathic pyroxenite, separated by hornfels interlayers. The latter do not appear to represent xenoliths as the three Platreef packages have distinct compositions (as discussed later). This occurrence of the Platreef is in marked contrast to that observed at Sandsloot open pit mine. Here, the mine geologists distinguish 3 layers of texturally distinct lithologies that form a continuous package. The A-reef is a feldspathic, pegmatoidal, pyroxenitic to noritic unit with a heterogeneous texture containing low-grade disseminated sulphide mineralisation. The B-reef is a coarse-grained feldspathic pyroxenite that locally contains chromitite stringers. Disseminated sulphides have higher metal tenors than in the A-reef. The unit also hosts unmineralised noritic bodies, up to several meters in width that tend to be fine-grained in the centre and coarser-grained (occasionally pegmatoidal) at the margins (Lachenicht, 2003). These rocks are termed hybrid norite by the mine geologists. It is not clear whether the hybrid norite is a distinct intrusive phase or represents metasomatised xenoliths. The $\mathbf{C}$-reef is a fine to medium-grained feldspathic pyroxenite with a 'brown sugar texture' and is normally poorly mineralised or barren. It is overlain, often with a relatively sharp contact, by the Main Zone gabbronorites. In some cases, a mottled anorthosite, up to $1 \mathrm{~m}$ thick occurs between the C-reef and the Main Zone gabbronorites.

The three gabbronorite horizons identified at Townlands are somewhat similar in texture and composition to the B-reef at Sandsloot whereas the A and $\mathrm{C}$ reefs do not appear to be developed at Townlands. For these reasons, the terminology of the Platreef as applied at Sandsloot will not be used in this work. Instead, the three platiniferous gabbronorite layers on Townlands will be referred to as the Lower, Middle and Upper Platreef units, from the bottom to the top, respectively.

\section{Stratigraphy}

The floor rocks of the Platreef consist of hornfels, quartzite and calcsilicates probably belonging to the early Proterozoic Silverton Formation of the Pretoria Group. The rocks are locally layered on a millimeter to centimeter scale with the layering defined by thin (1 to $2 \mathrm{~mm}$ ), dark, olivine bearing layers. The sedimentary rocks are intruded by numerous sill-like bodies of pyroxenite which show internal variation in grain size, from fine-grained at the margins to medium-grained in the centre. The width of the sills ranges from a few centimeters to several meters. Where in contact with the sills, the hornfels has thin reaction rims $(\leq 2 \mathrm{~mm})$, but apart from that, the contacts between the intrusions and the sedimentary rocks are sharp. Notably, no sills were observed within the Platreef. This may be a coincidence, or it may mean that the sills are older than the Platreef.
More information from other borehole intersections is necessary to constrain this question.

The Lower Platreef is noritic to gabbronoritic in composition, with less abundant pyroxenites. The contact between the Lower Platreef and the quartzitic floor rocks is formed by a hybrid zone which consists of highly altered metasedimentary rocks apparently injected by medium-grained, non-mineralised pyroxenite. Alternatively, the hybrid rock may represent pyroxenite containing a dense load of sedimentary xenoliths. A clear distinction between the two possibilities is not possible in the borehole core.

A $c a .9 \mathrm{~m}$ interlayer of ferruginous hornfels overlain by a $c a .3 \mathrm{~m}$ hybrid rock similar to the one described above separates the Lower Platreef from the Middle Platreef. The lower contact of the hornfels is sharp. The Middle Platreef is approximately $35 \mathrm{~m}$ thick and consists mainly of a medium-grained, olivine bearing, feldspathic pyroxenite/gabbronorite with a heterogeneous texture. Pegmatoidal patches are abundant and are due to a local increase in modal proportion and grain size of feldspars intergrown with dark, altered olivine and grayish-green pyroxene. Coarse sulphides of up to $3 \mathrm{~cm}$ in size are preferentially associated with the felsic pegmatoidal domains, whereas fine-grained sulphides are found in the more even-textured pyroxenite/gabbronorite. Xenoliths of metadolomite are not uncommon and are usually pervasively serpentinised. In the vicinity of the xenoliths, the igneous rocks show a progressive increase in the degree of serpentinisation and in modal olivine. Interaction between the xenoliths and the intrusive rocks is also evident in the form of coarse-grained to pegmatoidal textures in the intrusives surrounding the xenoliths.

A $c a .10 \mathrm{~m}$ hornfels interlayer (similar to the one between the Lower and Middle Platreef) overlain by a 3 $\mathrm{m}$ fine-grained barren pyroxenite sill $(59.55$ to $62.83 \mathrm{~m})$ separates the Middle Platreef from the Upper Platreef. The lower and upper contacts of the sill are sharp and the Platreef rocks adjoining the contact are mediumgrained feldspathic pyroxenite/gabbronorite, similar in appearance to the Middle Platreef but with an intervening $\mathrm{ca} .13 \mathrm{~m}$ noritic package (41.44 to $54.62 \mathrm{~m}$ ). Notably, there is no chilled margin developed at the basal contact of the Platreef with the hornfels. The gabbronorite has about 12 modal \% interstitial plagioclase in the upper portions decreasing to about 3 modal \% in the lower portions. Sulphides are mainly present in the form of fine disseminations and irregular interstitial blebs of pyrrhotite and minor chalcopyrite. More massive sulphide patches (up to $3 \mathrm{~cm}$ ) may also be developed locally. The Platreef norite has a markedly different appearance to the Platreef gabbronorite. It is medium-grained and contains 50 to 60 modal \% plagioclase and 40 to 50 modal \% orthopyroxene. Minor $(<1 \%)$ sulphides (chalcopyrite and pyrrhotite) occur as fine disseminations within the norite. The contact between the upper portion of the norite and the overlying pyroxenite/gabbronorite of the Upper Platreef 
Table 1. Precision and accuracy of the PGE analyses.

\begin{tabular}{|c|c|c|c|c|c|c|c|c|}
\hline & \multicolumn{4}{|l|}{ UTM-1 } & \multicolumn{4}{|l|}{ WGB-1 } \\
\hline & $\begin{array}{c}\text { UQAC } \\
\text { ppb }\end{array}$ & $\begin{array}{c}\mathbf{s} \\
+/-\end{array}$ & $\begin{array}{c}\text { CANMET } \\
\text { ppb }\end{array}$ & $\begin{array}{c}\text { error } \\
+/-\end{array}$ & $\begin{array}{c}\text { UQAC }^{*} \\
\text { ppb }\end{array}$ & $\begin{array}{c}\mathbf{s} \\
+/-\end{array}$ & $\begin{array}{c}\text { CANMET } \\
\text { ppb }\end{array}$ & $\begin{array}{c}\text { error } \\
+/-\end{array}$ \\
\hline Os ppb & 7.10 & 0.57 & 8.00 & 2.1 & 0.48 & 0.08 & n.v. & \\
\hline Ir & 10.00 & 0.40 & 8.80 & 0.60 & 0.25 & 0.04 & 0.33 & 0.27 \\
\hline $\mathrm{Ru}$ & 10.90 & 0.98 & 10.90 & 1.50 & $<1.20$ & 0.33 & 0.30 & 0.20 \\
\hline $\mathrm{Rh}$ & 10.80 & 0.43 & 9.50 & 1.10 & 0.46 & 0.08 & 0.32 & 0.19 \\
\hline $\mathrm{Pt}$ & 131.00 & 7.90 & 129.00 & 5.00 & 5.98 & 0.55 & 6.10 & 1.60 \\
\hline $\mathrm{Pd}$ & 110.00 & 4.40 & 106.00 & 3.00 & 13.20 & 1.94 & 13.9 & 2.10 \\
\hline $\mathrm{Au}$ & 47.90 & 4.30 & 48.00 & 2.00 & 1.34 & 0.59 & 2.90 & 1.10 \\
\hline
\end{tabular}

* $=\quad$ average of five NiS beads all fused, dissolved and irradiated in the same batch,

$\mathrm{s}=1$ sigma of the five values, CANMET Certificate of Analysis (1996). Note that the figures in italics are informational values only, i.e. there are as yet no certified values for these elements in these standards, the error in these cases are the standard deviation of the values submitted in the round robin tests.

n.v. $=$ no values

is defined by a $c a .1 .5 \mathrm{~m}$ fine-to medium-grained hornfels layer grading into a hybrid zone. The hornfels is highly magnetic with magnetite reaching up to 50 modal percent.

\section{Petrography}

The major silicate minerals of the Lower Platreef are subhedral or anhedral cumulus orthopyroxene $(55$ to 75 modal \%), mostly anhedral (intercumulus) and, to a lesser extent, subhedral (cumulus) plagioclase (20 to 40 modal \%) and interstitial clinopyroxene $(0-10$ modal \%). Accessory minerals include olivine, quartz, magnetite, sulphides and secondary biotite, amphibole, sericite and epidote. The relatively high amount of quartz (up to 3 modal $\%$ abundance) in some of the rocks is worthy of note.

The Middle Platreef is predominantly composed of cumulus orthopyroxene (65 to $80 \%$ ), interstitial and poikilitic clinopyroxene (10 to 15 modal \%) and plagioclase (10 to 25 modal \%). Plagioclase is mostly interstitial but subhedral plates of apparently cumulus origin are occasionally present. In addition, variable amounts of olivine (up to 20 modal \%) may occur. Minor phases are biotite, sulphides, magnetite and amphibole.

The Upper Platreef is predominantly composed of cumulus orthopyroxene (55 to 75 modal \%), with subordinate intercumulus clinopyroxene ( 0 to 20 modal $\%$ ) and intercumulus plagioclase (20 to 40 modal \%). Olivine, quartz, biotite, magnetite, sulphide and amphibole are minor phases.

\section{Analytical methods}

The mineral compositional data were determined using a JEOL JXA - 733 electron microprobe at Rhodes University, Grahamstown. The probe was operated at $20 \mathrm{kV}$ accelerating voltage, $30 \mathrm{nA}$ beam current and the samples were analysed using a $10 \mu \mathrm{m}$ beam diameter. K $\alpha$ was used for all elements. Counting times were 10 seconds on the peak position and 5 seconds on either side of the peak on the background. To improve the detection limits for $\mathrm{Ni}$, the counting time was set at
50 seconds on the peak and 25 seconds on the background.

Major elements were determined on fused beads, prepared following the standard method used in the $\mathrm{XRD}$ and XRF laboratory of the University of Pretoria, as adapted from Bennett and Oliver (2002). Trace elements were determined on pressed powder briquettes prepared following the method of Watson (1996).

The platinum-group elements, Re and Au were determined by instrumental neutron activation analysis (INAA) at the University of Quebec at Chicoutimi (UQAC). Details of the method are given in Bédard and Barnes (2002). Five determinations of five different NiS beads of the CANMET standard WGB-1 (Table 1) were used to estimate the precision and accuracy of the analyses. For all the elements except Au the relative standard deviations are 9 to $17 \%$. For $\mathrm{Au}, \mathrm{Pt}$ and $\mathrm{Pd}$ the accuracy of the analyses may be assessed by comparing the results obtained at UQAC for standards UTM-1 and WGB-1 with the certified values. The results are in good agreement with both the high- and low-level standard. For Rh, Ru and Ir certified values are available only for UTM-1. The UQAC analyses agree with the CANMET results. For the low-level standard WGB-1 only informational values are available for $\mathrm{Rh}, \mathrm{Ru}, \mathrm{Ir}$ and $\mathrm{Re}$. The results agree with these when the standard deviation on the CANMET informational value is considered.

No noble metals were detected in the blank, except Ir and $\mathrm{Au}$. These were present at 0.02 and $0.1 \mathrm{ppb}$, respectively. As both values are far lower than the levels present in the samples, no significant contamination is believed to have occurred in preparing the samples, and no blank correction was made on the samples.

$\mathrm{S}$-isotope ratios were measured using a Finnigan MAT252 isotope ratio mass spectrometer at Indiana University, Bloomington, USA, and are reported in the familiar $\delta$ notation relative to VCDT (Vienna Cañon Diablo Troilite). Sulphide powders and a small amount of $\mathrm{V}_{2} \mathrm{O}_{5}$ were loaded into tin capsules and analysed using Elemental Analyser-Continuous Flow Isotope Ratio 


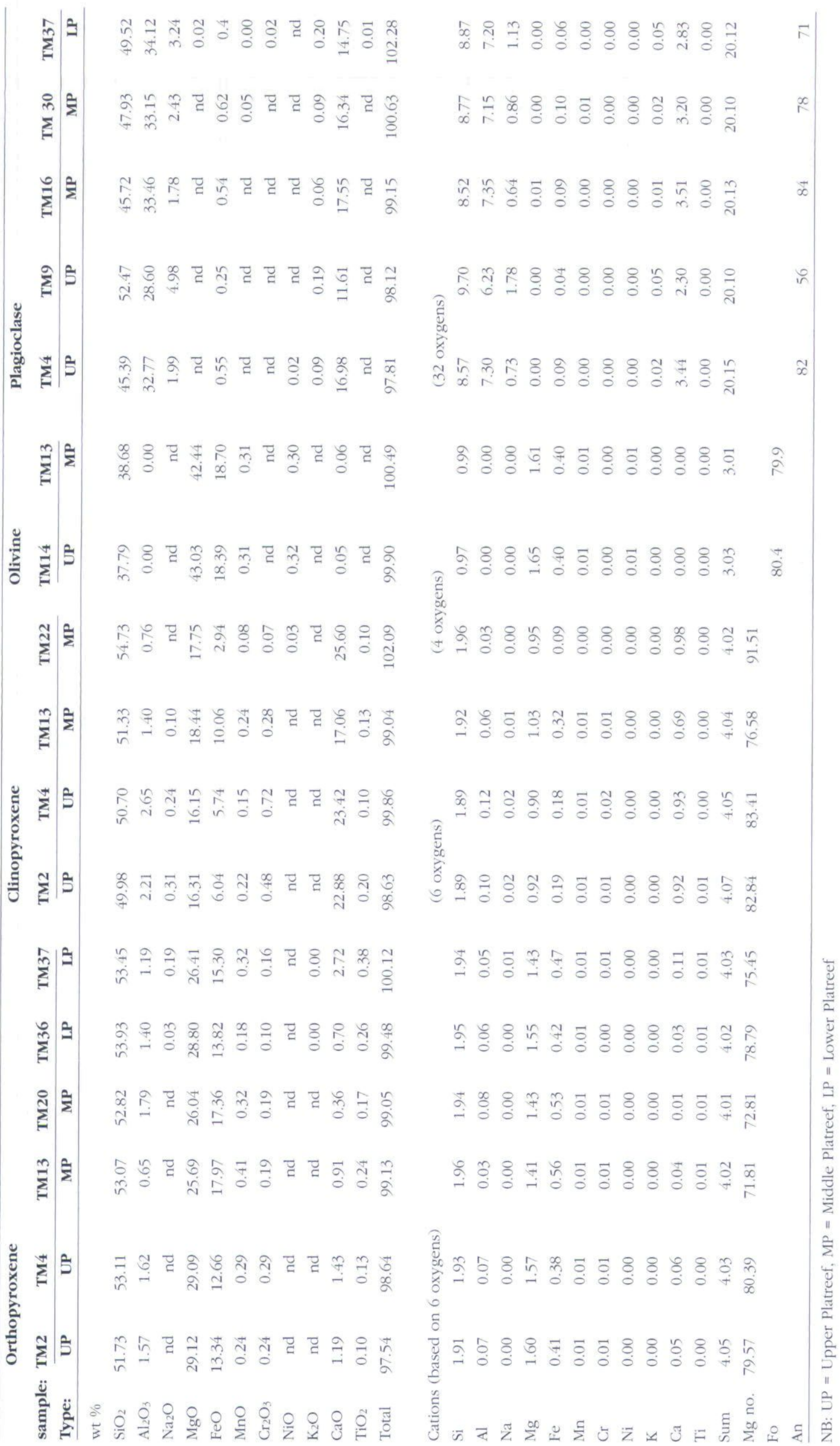




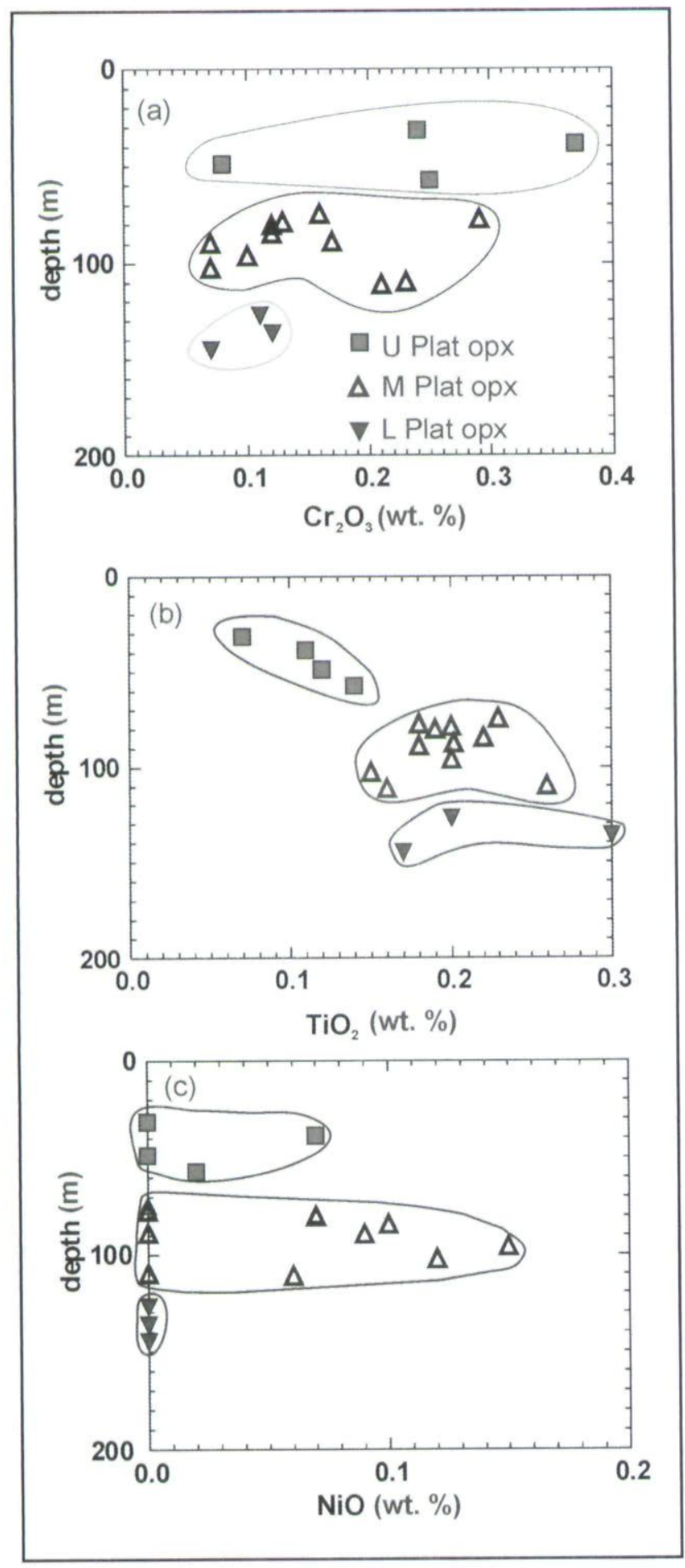

Figure 3. Plot of depth versus (a) $\mathrm{Cr}_{2} \mathrm{O}_{3}$ (b) $\mathrm{TiO}_{2}$ and (c) $\mathrm{NiO}$ in orthopyroxene $(o p x)$. U Plat $=$ Upper Platreef, M Plat $=$ Middle Platreef, L Plat $=$ Lower Platreef

Mass Spectrometry. Analytical precision was better than $\pm 0.05 \%$ and sample reproducibility was $\pm 0.1 \%$.

\section{Results}

\section{Mineral chemistry}

Selected analyses of orthopyroxene, olivine, plagioclase and clinopyroxene are given in Table 2. Orthopyroxenes are mainly enstatites and show a range of $\mathrm{Mg} \#$ between 68 and 82. Clinopyroxenes are mainly augites and diopsides, with Mg\# between 76 and 92 (Table 2).

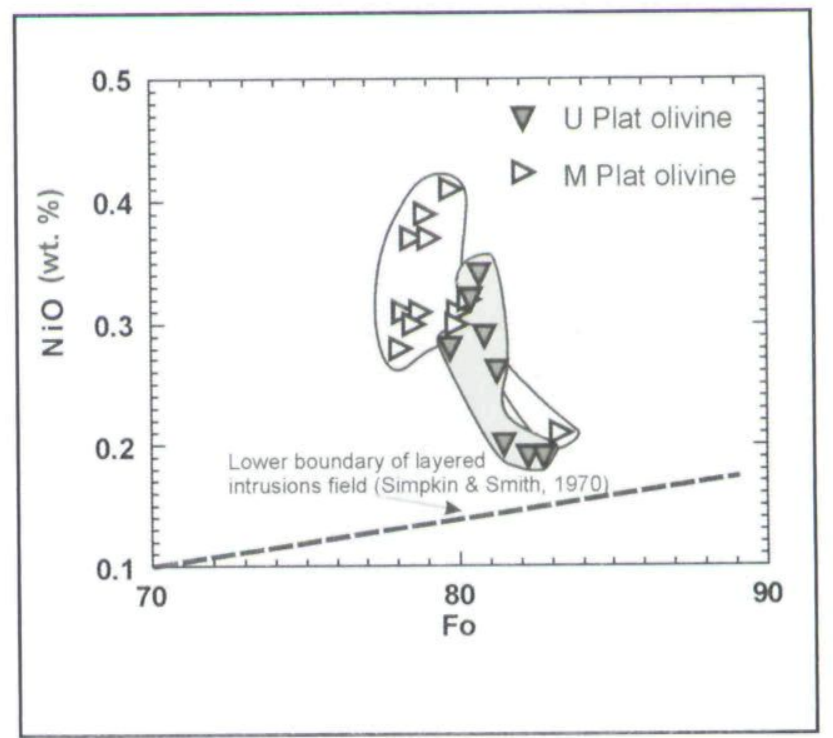

Figure 4. NiO versus Fo in Platreef olivine. Upper Platreef, M Plat $=$ platreef.

When plotted versus depth (Figure 3), orthopyroxene shows little systematic variation in terms of $\mathrm{Mg}^{*}$, but $\mathrm{Cr}_{2} \mathrm{O}_{3}$ broadly increases with height and $\mathrm{TiO}_{2}$ decreases. NiO contents show considerable variation, but the Lower Platreef orthopyroxenes tend to be particularly Ni-depleted (Figure 3).

There appears to be an analogous trend of $\mathrm{Cr}$ enrichment with height in the clinopyroxenes. Average $\mathrm{Cr}_{2} \mathrm{O}_{3}$ of clinopyroxene is 0.53 weight \% (maximum 0.72 weight \%) in the Upper Platreef and 0.20 weight $\%$ in the Middle Platreef. Clinopyroxenes in samples TM 19, TM 22 and TM 26 of the Middle Platreef are notable for their high $\mathrm{Al}_{2} \mathrm{O}_{3}$ contents (generally above 5 weight \%, reaching 9.68 weight $\%$ in sample TM 19). These clinopyroxenes also have slightly higher $\mathrm{CaO}$ contents of about 24 weight \% compared to the other clinopyroxenes which have $\mathrm{CaO}$ mostly between 21 to 22 weight \%. Based on the combined textural and compositional evidence, we suggest that these pyroxenes are of metamorphic origin, probably related to reaction of calcsilicate xenoliths with silicate magma.

No olivine was observed in the Lower Platreef. Olivine from the Upper and Middle Platreefs show a restricted compositional range. Analyses of core domains of olivine from the Upper Platreef display Fo contents between 80 to 83 (averaging $\mathrm{FO}_{81}$ ) and those from the Middle Platreef have Fo 78 to 83 (averaging $\mathrm{FO}_{79}$ ) (Figure 4). Thus the composition and distribution of olivine confirms the pattern of more primitive rock composition with height established by pyroxene compositions. $\mathrm{NiO}$ contents vary from 0.19 to 0.39 weight $\%$ (averaging 0.30 weight $\%$ ), which is consistent with a magmatic origin of the olivine. There is considerable local (within sample) variation in $\mathrm{Ni}$ content (not shown) possibly due to equilibration of olivine with sulphide.

Plagioclase plots in the labradorite and bytownite field of the An-Ab-Or triangle, with the exception of two 

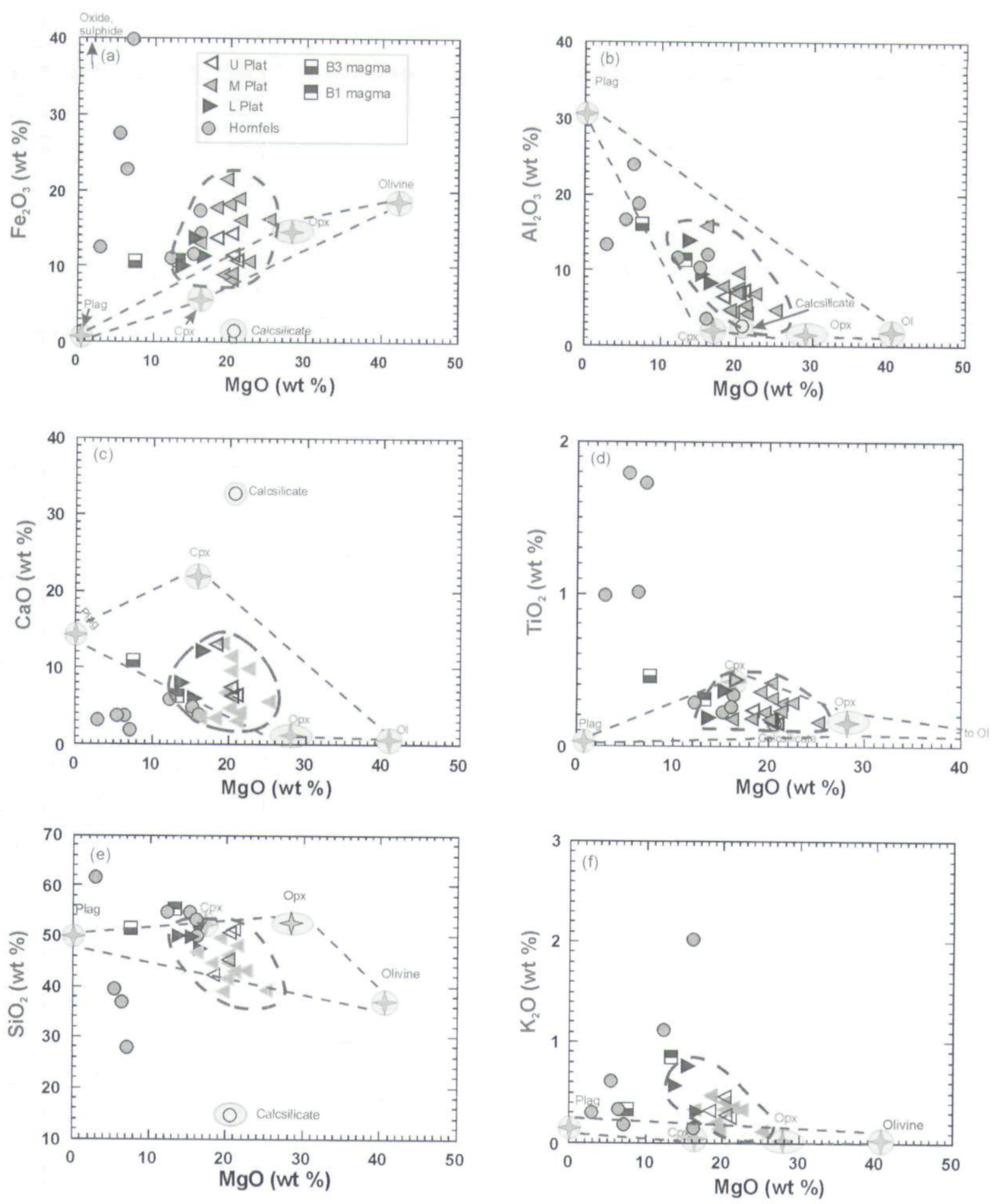

Figure 5. Plot of (a), $\mathrm{Fe}_{2} \mathrm{O}_{3}$, (b) $\mathrm{Al}_{2} \mathrm{O}_{3}$, (c) $\mathrm{CaO}$, (d) $\mathrm{TiO}_{2}$, (e) $\mathrm{SiO}_{2}$ and (f) $\mathrm{K}_{2} \mathrm{O}$ versus $\mathrm{MgO}$. Also plotted ar $\mathrm{B} 1$ and $\mathrm{B} 3$ Bushveld parental magmas (Curl, 2001) and averaged microprobe minerial compositions for the Platreef. U Plat $=$ Upper Platreef, $\mathrm{M}$ Plat $=$ Middle Platreef, L Plat $=$ Lower Platreef. Bold stippled line represents Platreef.

samples from TM 33 which plot in the oligoclase field. In all three Platreef layers, An contents range from 54 to 85.2 averaging 70.52 . These values are broadly similar to those of plagioclase from the Upper Critical Zone (UCZ) and Lower Main Zone in the Western Bushveld Complex (Maier and Eales, 1997; Mitchell, 1990). Two samples show An values of 25.8 and 28.7 and these may represent analyses from the rims of plagioclase grains.

\section{Whole rock chemistry}

Whole rock chemical analyses are given in Table 3. The data are displayed as bivariate plots with $\mathrm{MgO}$ as the differentiation index in Figure 5. Compositions of plagioclase, orthopyroxene, olivine, clinopyroxene and of B1 and B3 Bushveld parental magmas (Curl, 2001) were also plotted. This was done to determine whether the Platreef rocks are mixtures of the cumulus minerals 

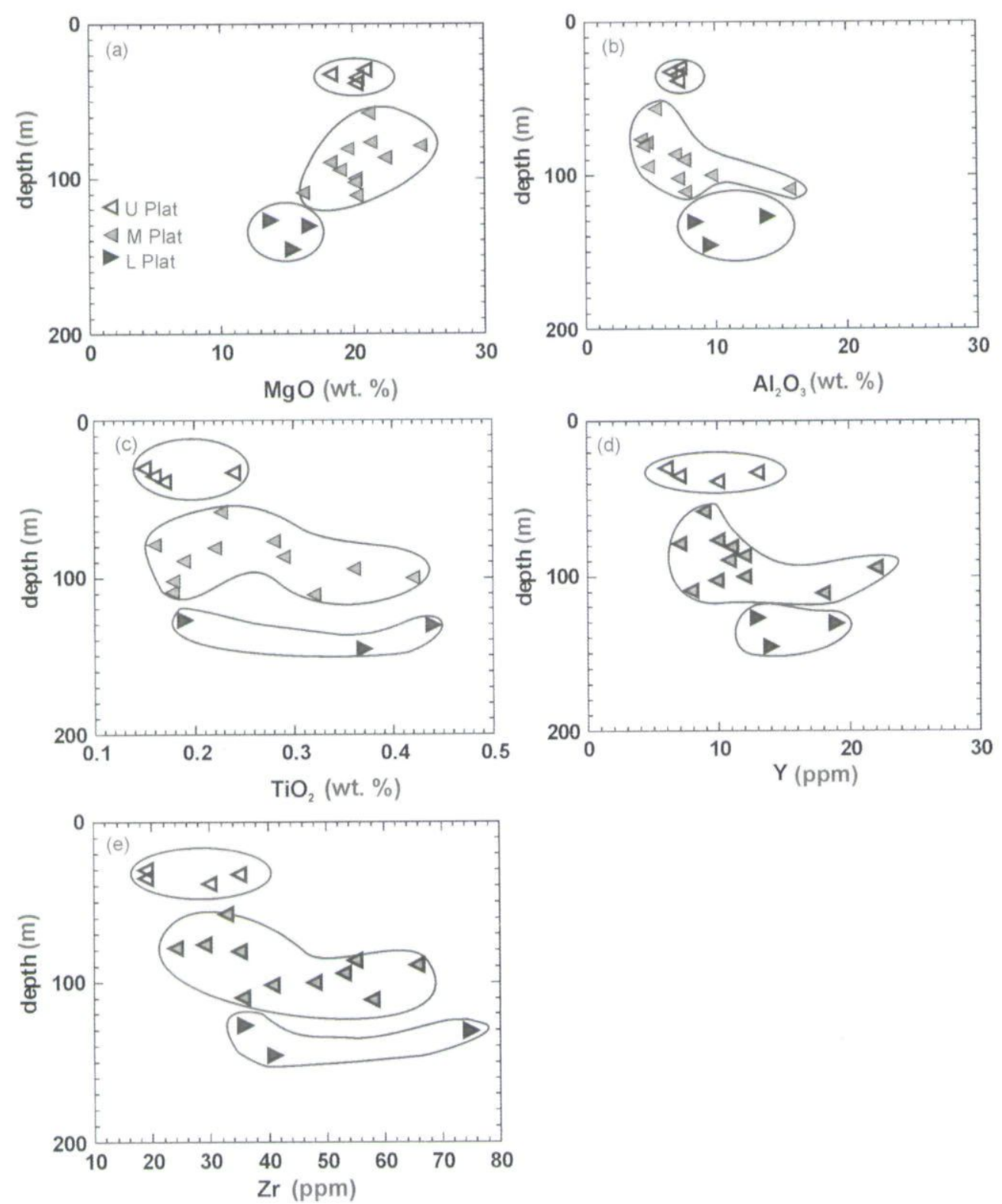

Figure 6. Plots of whole rock major and trace element concentration versus depth. (a) $\mathrm{MgO},(\mathbf{b}) \mathrm{Al}_{2} \mathrm{O}_{3}$, (c) $\mathrm{TiO}_{2}$, (d) $\mathrm{Y}$, (e) $\mathrm{Zr}$, versus depth U Plat $=$ Upper Platreef, $\mathrm{M}$ Plat $=$ Lower Platreef.

and trapped intercumulus melt of Bushveld lineage or whether there is an additional component present, possibly derived from the floor rocks.

It is notable that there is little correlation between $\mathrm{MgO}$ and $\mathrm{Fe}_{2} \mathrm{O}_{3}$ (Figure 5a), similar to that observed in the mafic-ultramafic rocks of the UCZ (Maier and Eales, 1997). It is possible that this is partly due to the presence of sulphides and/or Fe-oxides since several samples plot outside the compositional field defined by plagioclase, orthopyroxene, clinopyroxene and olivine. In terms of $\mathrm{Al}_{2} \mathrm{O}_{3}, \mathrm{CaO}$ and $\mathrm{TiO}_{2}$, little evidence for the addition of components from the country rocks is evident (Figures 5b, c and d, respectively). In contrast, the $\mathrm{SiO}_{2}$ versus $\mathrm{MgO}$ diagram (Figure $5 \mathrm{e}$ ) may indicate a component of calcsilicate and/ or shale in the rocks.
The high $\mathrm{K}_{2} \mathrm{O}$ contents of the rocks support this model. Selected major elements are plotted versus depth in figure 6. The data show a broad increase in $\mathrm{MgO}$ with height, and decreases in $\mathrm{TiO}_{2}$ and $\mathrm{Al}_{2} \mathrm{O}_{3}$, confirming the trend shown by the mineral chemistry data that indicated a reverse differentiation trend in the Platreef with height.

In terms of the trace elements, it is evident that relative to the Merensky reef, the Platreef has high contents of incompatible elements $\mathrm{Sr}, \mathrm{Rb}, \mathrm{Zr}, \mathrm{Y}, \mathrm{Nb}, \mathrm{V}$ as well as chalcophile elements $\mathrm{Cu}$ and $\mathrm{Ni}$ but low contents of the more compatible elements $\mathrm{Cr}, \mathrm{Sc}$ and $\mathrm{Zn}$ (Table 3). Cr shows a general increase in concentration towards the top of the Platreef, confirming that the upper Platreef layers are relatively more primitive, as was suggested by the mineral chemistry data. 
Table 3: Whole rock analyses

\begin{tabular}{|c|c|c|c|c|c|c|c|c|c|c|c|c|c|c|c|c|c|}
\hline $\begin{array}{l}\text { sample } \\
\text { Unit }\end{array}$ & $\begin{array}{l}\text { P1 } \\
\text { UP }\end{array}$ & $\begin{array}{l}\text { P2 } \\
\text { UP }\end{array}$ & $\begin{array}{l}\text { P3 } \\
\text { UP }\end{array}$ & $\begin{array}{l}\text { P4 } \\
\text { UP }\end{array}$ & $\begin{array}{r}\text { P5 } \\
\text { Gabbro } \\
\text { sill }\end{array}$ & $\begin{array}{r}\text { P6 } \\
\text { Norite } \\
\text { sill }\end{array}$ & $\begin{array}{l}\text { P7 } \\
\text { UP }\end{array}$ & $\begin{array}{r}\text { P8 } \\
\text { Gabbro } \\
\text { sill }\end{array}$ & $\begin{array}{c}\text { P9 } \\
\text { hornfelsho }\end{array}$ & $\begin{array}{r}\text { P10 } \\
\text { ornfels }\end{array}$ & $\begin{array}{l}\text { P11 } \\
\text { MP }\end{array}$ & $\begin{array}{l}\text { P12 } \\
\text { MP }\end{array}$ & $\begin{array}{r}\text { P13 } \\
\text { MP }\end{array}$ & $\begin{array}{l}\text { P14 } \\
\text { MP }\end{array}$ & $\begin{array}{l}\text { P15 } \\
\text { MP }\end{array}$ & $\begin{array}{l}\text { P16 } \\
\text { MP }\end{array}$ & $\begin{array}{r}\text { P17 } \\
\text { skarn }\end{array}$ \\
\hline depth (n & m)30.4 & 32.69 & 34.91 & 38.85 & 44.77 & 44.77 & 57.7 & 62.65 & 63.65 & 68.3 & 76.99 & 78.74 & 80.75 & 86.42 & 89.55 & 94.3 & 96.6 \\
\hline \multicolumn{18}{|l|}{ wt $\%$} \\
\hline $\mathrm{SiO}_{2}$ & 52.37 & 43.74 & 52.19 & 46.79 & 52.03 & 52.06 & 43.18 & 52.65 & 28.11 & 50.35 & 49.49 & 42.09 & 39.37 & 45.26 & 45.55 & 51.49 & 39.12 \\
\hline $\mathrm{TiO}_{2}$ & 0.15 & 0.25 & 0.16 & 0.18 & 0.30 & 0.30 & 0.23 & 0.16 & 1.75 & 0.34 & 0.29 & 0.17 & 0.22 & 0.30 & 0.19 & 0.37 & 0.32 \\
\hline $\mathrm{Al}_{2} \mathrm{O}_{3}$ & 7.43 & 6.73 & 7.20 & 7.40 & 10.38 & 10.38 & 5.56 & 22.57 & 18.98 & 12.23 & 4.40 & 5.04 & 4.43 & 7.24 & 7.88 & 4.92 & 10.10 \\
\hline $\mathrm{Fe}_{2} \mathrm{O}_{3}$ & 10.94 & 14.19 & 11.77 & 14.91 & 6.93 & 6.93 & 19.15 & 5.70 & 40.31 & 14.52 & 16.56 & 17.49 & 21.67 & 11.10 & 18.17 & 9.20 & 12.35 \\
\hline $\mathrm{MnO}$ & 0.21 & 0.20 & 0.24 & 0.21 & 0.14 & 0.14 & 0.21 & 0.09 & 0.20 & 0.23 & 0.27 & 0.28 & 0.18 & 0.14 & 0.18 & 0.14 & 0.14 \\
\hline $\mathrm{MgO}$ & 21.31 & 18.92 & 20.97 & 20.98 & 10.05 & 10,05 & 21.58 & 5.48 & 7.24 & 16.39 & 22.00 & 27.05 & 19.71 & 23.59 & 18.83 & 19.79 & 35.93 \\
\hline $\mathrm{CaO}$ & 6.65 & 13.53 & 6.52 & 7.80 & 18.24 & 18.25 & 3.24 & 9.21 & 1.97 & 3.83 & 4.29 & 6.01 & 6.82 & 10.35 & 3.60 & 13.75 & 1.01 \\
\hline $\mathrm{Na}_{2} \mathrm{O}$ & 0.13 & 0.01 & 0.04 & 0.01 & 1.07 & 1.07 & 0.01 & 3.41 & 1.07 & 1.65 & 0.01 & 0.01 & 0.01 & 0.01 & 0.01 & 0.01 & 0.01 \\
\hline $\mathrm{K}_{2} \mathrm{O}$ & 0.27 & 0.33 & 0.29 & 0.48 & 0.68 & 0.68 & 0.34 & 0.47 & 0.18 & 0.15 & 0.37 & 0.13 & 0.14 & 0.35 & 0.49 & 0.22 & 0.07 \\
\hline $\mathrm{P}_{2} \mathrm{O}_{5}$ & 0.01 & 0.03 & 0.01 & 0.02 & 0.04 & 0.04 & 0.05 & 0.03 & 0.01 & 0.02 & 0.03 & 0.03 & 0.02 & 0.03 & 0.03 & 0.02 & 0.01 \\
\hline $\mathrm{Cr}_{2} \mathrm{O}_{3}$ & 0.42 & 0.04 & 0.46 & 0.33 & 0.04 & 0.03 & 0.30 & 0.07 & 0.15 & 0.23 & 0.21 & 0.11 & 0.20 & 0.04 & 0.10 & 0.05 & 0.03 \\
\hline $\mathrm{Ni}$ & 0.06 & 0.37 & 0.06 & 0.16 & 0.03 & 0.03 & 0.73 & 0.01 & 0.03 & 0.03 & 0.48 & 0.38 & 1.42 & 0.28 & 0.76 & 0.02 & 0.15 \\
\hline S & 0.04 & 1.42 & 0.07 & 0.71 & 0.08 & 0.03 & 4.98 & 0.13 & 0.00 & 0.01 & 1.38 & 1.01 & 5.45 & 1.16 & 3.37 & 0.01 & 0.63 \\
\hline $\mathrm{Cu}$ & 0.02 & 0.26 & 0.01 & 0.01 & 0.00 & 0.00 & 0.43 & 0.00 & 0.00 & 0.00 & 0.25 & 0.25 & 0.35 & 0.15 & 0.85 & 0.00 & 0.16 \\
\hline TOTAL & 100.00 & 100.02 & 100.00 & 100.00 & 100.00 & 100.00 & 100.00 & 100.00 & 100.00 & 100.00 & 100.02 & 100.04 & 100.00 & 100.00 & 100.00 & 100.01 & 100.03 \\
\hline LOI & 0.43 & 3.2 & 1.13 & 2.6 & 1.58 & 1.54 & 4.27 & 1.44 & . & . & 1.18 & 6.19 & 4.78 & 5.60 & 3.35 & 1.95 & 11.53 \\
\hline
\end{tabular}

Trace elements (ppm)

\begin{tabular}{|c|c|c|c|c|c|c|c|c|c|c|c|c|c|c|c|c|c|}
\hline As & 3 & 3 & 3 & 4 & 3 & 3 & 10 & 3 & 6 & 3 & 3 & 3 & 6 & 6 & 3 & 3 & 3 \\
\hline $\mathrm{Cu}$ & 153 & 2544 & 135 & 143 & 14 & 14 & 4274 & 9 & 24 & 4 & 2473 & 2320 & 3533 & 1471 & 8510 & 18 & 1448 \\
\hline Ga & 8 & 9 & 8 & 8 & 12 & 12 & 9 & 22 & 65 & 14 & 7 & 8 & 8 & 8 & 11 & 8 & 14 \\
\hline $\mathrm{Nb}$ & 3 & 2 & 2 & 2 & 4 & 4 & 5 & 2 & 3 & 3 & 3 & 2 & 2 & 4 & 3 & 3 & 3 \\
\hline $\mathrm{Ni}$ & 583 & 3564 & 629 & 1535 & 281 & 282 & 7346 & 120 & 287 & 302 & 4665 & 3501 & 14166 & 2818 & 7568 & 210 & 1303 \\
\hline $\mathrm{Pb}$ & 6 & 48 & 13 & 24 & 17 & 17 & 31 & 16 & 11 & 9 & 20 & 16 & 37 & 34 & 28 & 4 & 14 \\
\hline $\mathrm{Rb}$ & 12 & 18 & 12 & 26 & 32 & 32 & 19 & 16 & 11 & 3 & 22 & 8 & 10 & 17 & 27 & 14 & 6 \\
\hline $\mathrm{Sr}$ & 149 & 160 & 106 & 214 & 170 & 170 & 174 & 650 & 482 & 355 & 60 & 75 & 74 & 107 & 231 & 117 & 16 \\
\hline Y & 6 & 13 & 7 & 10 & 31 & 31 & 9 & 7 & 5 & 11 & 10 & 8 & 11 & 13 & 11 & 23 & 6 \\
\hline $\mathrm{Zn}$ & 83 & 108 & 112 & 109 & 70 & 70 & 144 & 56 & 409 & 128 & 129 & 125 & 111 & 78 & 144 & 64 & 192 \\
\hline $\mathrm{Zr}$ & 19 & 36 & 20 & 30 & 54 & 54 & 33 & 21 & 27 & 31 & 30 & 26 & 35 & 58 & 67 & 55 & 44 \\
\hline Co & 89 & 117 & 93 & 124 & 41 & 41 & 308 & 25 & 159 & 90 & 171 & 146 & 294 & 96 & 174 & 56 & 82 \\
\hline $\mathrm{Cr}$ & 2876 & 259 & 3116 & 2361 & 257 & 257 & 2080 & 463 & 1016 & 1576 & 1605 & 758 & 1391 & 261 & 660 & 406 & 208 \\
\hline $\mathrm{Sc}$ & 19 & 12 & 22 & 12 & 41 & 41 & 12 & 2 & 16 & 40 & 20 & 5 & 7 & 7 & 11 & 10 & 17 \\
\hline V & 100 & 116 & 102 & 78 & 80 & 80 & 66 & 33 & 451 & 108 & 122 & 71 & 83 & 80 & 66 & 114 & 55 \\
\hline $\begin{array}{l}\text { s } \\
\text { ppm }\end{array}$ & 377 & 14189 & 700 & 7136 & 778 & 303 & 49817 & 1295 & 16 & 81 & 13765 & 10059 & 54522 & 11555 & 33706 & 130 & 6286 \\
\hline Ba & 163 & 233 & 90 & 217 & 160 & 270 & 124 & 275 & 140 & 107 & 102 & 61 & 74 & 114 & 164 & 47 & na \\
\hline Cs & 0.86 & 2.44 & 1.23 & 1.88 & 2.05 & 1.37 & 1.64 & 1.41 & 1.73 & 0.52 & 1.17 & 1.23 & 1.63 & 1.44 & 2.10 & 1.45 & na \\
\hline Hf & 0.18 & 0.84 & 0.30 & 0.59 & 1.64 & 064 & 0.69 & 0.29 & 0.56 & 0.86 & 0.44 & 0.45 & 0.62 & 1.56 & 1.51 & 1.44 & na \\
\hline $\mathrm{Ta}$ & 0.10 & 0.22 & $<0.11$ & 0.10 & 0.22 & $<0.15$ & 0.13 & $<0.22$ & 0.08 & 0.05 & 0.06 & $<0.092$ & 0.06 & 0.10 & 0.13 & 0.17 & na \\
\hline Th & 0.33 & 0.58 & 0.49 & 1.15 & 2.02 & 0.97 & 1.00 & 0.58 & 0.22 & 0.32 & 0.79 & 0.53 & 0.75 & 1.18 & 1.48 & 1.05 & na \\
\hline U & 0.2 & 0.2 & 0.1 & 0.3 & 0.8 & 0.3 & 0.8 & 0.1 & 0.1 & 0.1 & 0.4 & 0.1 & 0.2 & 0.2 & 0.2 & 0.3 & na \\
\hline $\mathrm{La}$ & 1.84 & 4.20 & 1.87 & 4.67 & 10.20 & 9.34 & 7.43 & 11.86 & 8.41 & 9.27 & 4.24 & 3.16 & 4.24 & 5.55 & 6.94 & 8.87 & na \\
\hline $\mathrm{Ce}$ & 4.41 & 1245 & 3.98 & 12.43 & 38.65 & 20.43 & 14.17 & 22.06 & 12.28 & 16.78 & 8.51 & 7.85 & 10.04 & 13.87 & 13.30 & 30.93 & na \\
\hline $\mathrm{Nd}$ & 2.72 & 4.58 & 1.59 & 4.14 & 20.11 & 5.69 & 4.57 & 7.09 & 3.66 & 4.62 & 3.41 & 2.95 & 4.02 & 6.51 & 4.46 & 16.08 & na \\
\hline Sm & 0.49 & 1.29 & 0.50 & 1.20 & 5.27 & 1.10 & 1.09 & 0.99 & 0.50 & 0.84 & 0.93 & 0.76 & 1.18 & 1.44 & 0.99 & 3.31 & na \\
\hline Eu & 0.20 & 0.46 & 0.20 & 0.38 & 0.99 & 0.70 & 0.50 & 0.89 & 0.49 & 0.56 & 0.39 & 0.30 & 0.60 & 0.47 & 0.55 & 0.85 & na \\
\hline $\mathrm{Tb}$ & 0.06 & 0.22 & 0.09 & 0.17 & 0.92 & 0.17 & 0.09 & 0.11 & 0.05 & 0.14 & 0.12 & 0.14 & 0.11 & 0.24 & 0.17 & 0.54 & na \\
\hline $\mathrm{Yb}$ & 0.48 & 0.66 & 0.51 & 0.64 & 2.32 & 0.71 & 0.67 & 0.40 & 0.16 & 1.26 & 0.75 & 0.46 & 0.66 & 0.73 & 0.90 & 1.64 & na \\
\hline $\begin{array}{l}\text { Lu } \\
\text { ppb }\end{array}$ & 0.087 & 0.125 & 0.082 & 0.110 & 0.333 & 0.129 & 0.113 & 0.062 & 0.031 & 0.225 & 0.126 & 0.075 & 0.107 & 0.118 & 0.151 & 0.250 & na \\
\hline Os & 8.4 & 4.6 & 1.5 & 3.2 & $<1.1$ & 1.4 & 20.1 & $<1.5$ & 1.1 & 0.9 & 7.3 & 4.7 & 21.6 & 2.5 & 6.3 & 1.3 & na \\
\hline Ir & 7.49 & 4.43 & 2.01 & 3.00 & 0.14 & 1.44 & 21.85 & 0.14 & 0.31 & 0.58 & 8.66 & 5.28 & 24.75 & 1.07 & 10.22 & 0.05 & na \\
\hline Ru & 58 & 23 & 12 & 11.7 & $<4$ & 3.6 & 106 & $<5.9$ & 7.6 & 2 & 33.6 & 24.8 & 35 & $<7.3$ & $<9.3$ & 3.9 & na \\
\hline $\mathrm{Rh}$ & 21.6 & 23.2 & 42 & 12.3 & 0.3 & 7.9 & 86.4 & 0.4 & 0.47 & 1.4 & 37.4 & 20.6 & 107.7 & 7.1 & 34.9 & 0.53 & na \\
\hline $\mathrm{Pt}$ & 319 & 362 & 64 & 227 & 8 & 96 & 1592 & 8 & 6.23 & 21 & 428 & 245 & 727 & 633 & 311 & 9.5 & na \\
\hline Pd & 112 & 771 & 44 & 348 & 4 & 277 & 1665 & $<6$ & 4.85 & $<6$ & 962 & 423 & 3409 & 1142 & 953 & 8.3 & na \\
\hline $\mathrm{Au}$ & 7.0 & 65.3 & 7.7 & 35.9 & 0.5 & 161.0 & 191.0 & 0.5 & 0.36 & 0.6 & 143.8 & 61.0 & 142.6 & 79.1 & 186.0 & 0.41 & na \\
\hline $\operatorname{Re}$ & 0.3 & 3.8 & $<0.3$ & 0.2 & $<0.1$ & 0.4 & 13.3 & $<0.4$ & 0.26 & $<0.4$ & 8.8 & 2.6 & 28.2 & 4.2 & $<0.6$ & 0.2 & na \\
\hline
\end{tabular}

= not detected $s=$ telow dection LOI free

* = Average calculated form Wilson et al. (1999)

The concentrations of the incompatible trace elements $\mathrm{Y}$ and $\mathrm{Zr}$ decrease with height (Figures $6 \mathrm{~d}$ and $\mathrm{e}$, respectively).

Chondrite-normalised REE patterns for the Platreef rocks are shown in Figure $7 \mathrm{a}$ to $\mathrm{c}$. The patterns are relatively fractionated with LREE being strongly enriched over the HREE. The Lower and Middle Platreef have REE concentrations covering the range 3.5 to 35 and 2 to 35 times chondrite, respectively, and the Upper Platreef covers the range 1 to 15 times chondrite. The Lower Platreef shows the most fractionated patterns with $\mathrm{Ce} / \mathrm{Sm}_{\mathrm{N}} 2.7$ to 3.1 compared to 2.0 to 2.5 and 1.9 to 2.5 for the Middle Platreef and Upper Platreef, respectively. $\mathrm{Ce} / \mathrm{Sm}$ ratios are plotted versus depth in Figure $7 \mathrm{~d}$.
The ratios generally increase with depth. Notably, Lower and Lower Critical Zone rocks have higher $\mathrm{Ce} / \mathrm{Sm}$ ratios i.e. 10 to 20 and 11 to 25 , respectively (Maier and Barnes, 1998) suggesting that they crystallised from a magma that is more strongly LREE enriched than the parental magmas to the Platreef rocks. The Main Zone has $\mathrm{Ce} / \mathrm{Sm}$ ratios ranging from 5 to 12 (average 8 to 9) which is more comparable to the observed Platreef ratios (Figure $7 \mathrm{~d}$ ).

The HREE are relatively unfractionated; $\mathrm{Tb} / \mathrm{Yb}_{\mathrm{N}}$ is 0.50 to 1.39 (average 0.93 ) for the Upper Platreef, 0.70 to 1.46 (average 1.16) for the Middle Platreef and 1.04 to 1.37 (average 1.17) for the Lower Platreef. In general, no Eu anomaly is evident in most of the Platreef rocks. 


\begin{tabular}{|c|c|c|c|c|c|c|c|c|c|c|c|c|c|c|c|}
\hline P18 & P19 & P20 & P21 & P22 & P23 & P24 & P25 & P26 & P28 & P29 & P30 & P31 & P32 & \multicolumn{2}{|c|}{ P33Merensky } \\
\hline MP & MP & MP & MP & hornfels & hornfels & LP & $\mathbf{L P}$ & LP & hornfels & hornfels & $\begin{array}{l}\text { dolomite h } \\
\text { xenolith }\end{array}$ & iornfels & hornfels 1 & hornfels & Reef \\
\hline 100.05 & 102.35 & 109.82 & 110.95 & 112.75 & 118.95 & 126.9 & 138.38 & 145.6 & 170.4 & 174.95 & 189.95 & 197.37 & 205.18 & 213 & \\
\hline 47.75 & 43.49 & 47.58 & 48.11 & 38.01 & 56.16 & 50.97 & 48.73 & 50.97 & 63.09 & 55.58 & 35.55 & 39.90 & 53.40 & 20.02 & 51.09 \\
\hline 0.45 & 0.19 & 0.18 & 0.33 & 1.04 & 0.30 & 0.19 & 0.45 & 0.38 & 1.01 & 0.22 & 0.18 & 1.81 & 0.26 & 0.21 & 0.22 \\
\hline 10.31 & 7.52 & 16.08 & 7.97 & 24.67 & 11.92 & 14.16 & 8.58 & 9.76 & 13.59 & 10.52 & 7.96 & 16.74 & 3.67 & 3.75 & 10.6 \\
\hline 8.82 & 19.00 & 13.44 & 9.44 & 23.41 & 11.36 & 10.28 & 11.66 & 14.17 & 12.72 & 11.78 & 4.55 & 27.74 & 17.46 & 2.12 & 9.58 \\
\hline 0.13 & 0.18 & 0.16 & 0.17 & 0.16 & 0.20 & 0.18 & 0.23 & 0.21 & 0.09 & 0.20 & 0.17 & 0.13 & 0.29 & 0.07 & 0.16 \\
\hline 21.63 & 21.14 & 16.64 & 21.15 & 6.52 & 12.59 & 14.05 & 17.11 & 15.81 & 2.97 & 15.45 & 42.66 & 5.45 & 16.11 & 28.43 & 18.89 \\
\hline 10.34 & 4.77 & 3.58 & 11.96 & 3.85 & 5.99 & 8.15 & 12.55 & 6.19 & 3.26 & 5.01 & 7.88 & 3.80 & 3.94 & 45.31 & 6.2 \\
\hline 0.01 & 0.01 & 0.53 & 0.01 & 1.55 & 0.07 & 1.06 & 0.03 & 0.01 & 2.36 & 0.53 & 0.01 & 3.27 & 0.69 & 0.00 & 0.75 \\
\hline 0.47 & 0.43 & 0.35 & 0.35 & 0.34 & 1.15 & 0.58 & 0.32 & 0.78 & 0.31 & 0.37 & 0.02 & 0.62 & 2.03 & 0.01 & 0.20 \\
\hline 0.07 & 0.03 & 0.07 & 0.03 & 0.03 & 0.05 & 0.20 & 0.08 & 0.06 & 0.05 & 0.05 & 0.01 & 0.03 & 1.56 & 0.08 & 0.03 \\
\hline 001 & 0.07 & 0.06 & 0.04 & 0.07 & 0.18 & 0.10 & 0.10 & 0.36 & 0.03 & 0.24 & 0.01 & 0.10 & 0.05 & 0.00 & 1.08 \\
\hline 0.01 & 0.43 & 0.23 & 0.08 & 0.01 & 0.02 & 0.03 & 0.04 & 0.20 & 0.01 & 0.04 & 0.00 & 0.02 & 0.02 & 0.00 & 0.23 \\
\hline 0.00 & 2.29 & 0.90 & 0.30 & 0.33 & 0.01 & 0.02 & 0.09 & 0.72 & 0.50 & 0.00 & 0.98 & 0.37 & 0.49 & 0.00 & 0.51 \\
\hline 0.00 & 0.46 & 0.22 & 0,06 & 0.00 & 0.00 & 0.00 & 0.02 & 0.36 & 0.00 & 0.00 & 0.00 & 0.01 & 0.03 & 0.00 & 0.08 \\
\hline 100.00 & 100.00 & 100.01 & 100.00 & 100.00 & 100.00 & 100.00 & 100.00 & 100.00 & 100.00 & 100.00 & 100.00 & 100.00 & 100.00 & 100.00 & 99,6 \\
\hline 5.7 & 4.88 & 2.21 & 2.80 & 1.31 & 1.07 & 1.16 & 1.52 & 1.83 & 169 & 0.28 & 13.85 & . & $\cdot$ & 37.41 & \\
\hline
\end{tabular}

\begin{tabular}{|c|c|c|c|c|c|c|c|c|c|c|c|c|c|c|c|}
\hline 3 & 9 & 5 & 3 & 3 & 4 & 3 & 3 & 6 & 6 & 3 & 3 & 6 & 3 & 4 & $<5$ \\
\hline 25 & 4648 & 2173 & 609 & 39 & 5 & 47 & 203 & 3609 & 6 & 5 & 5 & 125 & 343 & 3 & 811 \\
\hline 14 & 10 & 17 & 10 & 43 & 11 & 14 & 12 & 12 & 22 & 10 & 11 & 40 & 7 & 7 & na \\
\hline 4 & 2 & 2 & 5 & 3 & 3 & 3 & 4 & 3 & 7 & 4 & 6 & 4 & 5 & 7 & na \\
\hline 62 & 4292 & 2230 & 775 & 122 & 237 & 313 & 437 & 2039 & 63 & 408 & 27 & 241 & 178 & 15 & 2300 \\
\hline 3 & 10 & 16 & 22 & 16 & 5 & 37 & 23 & 11 & 9 & 5 & 3 & 13 & 12 & 6 & na \\
\hline 25 & 24 & 24 & 16 & 20 & 42 & 22 & 17 & 35 & 11 & 21 & 6 & 21 & 93 & 4 & 6 \\
\hline 248 & 156 & 210 & 201 & 755 & 344 & 308 & 284 & 417 & 439 & 111 & 15 & 640 & 113 & 158 & $108.51=$ \\
\hline 13 & 10 & 8 & 19 & 7 & 11 & 13 & 20 & 14 & 21 & 10 & 7 & 8 & 50 & 14 & na \\
\hline 80 & 120 & 120 & 71 & 186 & 196 & 88 & 85 & 83 & 74 & 103 & 75 & 200 & 181 & 26 & na \\
\hline 51 & 43 & 37 & 60 & 56 & 36 & 37 & 77 & 42 & 212 & 42 & 22 & 39 & 70 & 80 & $28.47=$ \\
\hline 48 & 177 & 125 & 68 & 96 & 72 & 67 & 82 & 115 & 53 & 79 & 19 & 112 & 91 & 3 & 106 \\
\hline 61 & 446 & 454 & 294 & 454 & 1210 & 697 & 734 & 2470 & 238 & 1745 & 71 & 701 & 393 & 18 & 0.74 \\
\hline 14 & 8 & 17 & 8 & 7 & 33 & 16 & 13 & 22 & 11 & 33 & 2 & 18 & 17 & 1 & 24 \\
\hline 103 & 62 & 67 & 92 & 213 & 148 & 70 & 136 & 116 & 151 & 153 & 7 & 377 & 49 & 17 & 100 \\
\hline 17 & 22852 & 8966 & 3031 & 3251 & 113 & 163 & 868 & 7230 & 4991 & 16 & 9778 & 3746 & 4895 & 0 & 5100 \\
\hline na & 143 & 204 & 119 & 166 & 307 & 234 & 171 & 369 & 351 & na & na & 2 & 1 & na & 61 \\
\hline na & 3.03 & 5.81 & 1.20 & 3.03 & 1.16 & 1.61 & 1.57 & 1.04 & 2.38 & na & na & 10.66 & 2.33 & na & 0.09 \\
\hline na & 0.94 & 0.70 & 1.48 & 1.38 & 0.65 & 0.68 & 1.73 & 0.83 & 5.59 & $\mathrm{na}$ & na & 0.67 & 0.07 & na & 1 \\
\hline na & 0.28 & 0.27 & 0.27 & 0.14 & 0.11 & 0.11 & 0.26 & 0.15 & 0.45 & na & na & 0.27 & 0.11 & na & 0.04 \\
\hline na & 2.40 & 1.19 & 2.16 & 0.56 & 0.95 & 1.62 & 3.07 & 1.14 & 4.34 & na & na & 11.08 & 0.26 & na & 1 \\
\hline na & 0.5 & 0.4 & 0.4 & 0.1 & 0.2 & 0.6 & 0.6 & 0.3 & 0.8 & na & na & 3.0 & $<0,13$ & na & 0.11 \\
\hline na & 6.25 & 7.10 & 9.47 & 18.44 & 7.82 & 8.66 & 12.68 & 7.22 & 40.21 & na & na & 232.08 & 38.04 & na & 3.29 \\
\hline na & 13.66 & 13.26 & 26.01 & 33.97 & 17.22 & 19.55 & 31.97 & 17.65 & 86.86 & na & na & 97.94 & 11.94 & na & 6.81 \\
\hline na & 5.55 & 3.12 & 10.96 & 11.99 & 6.61 & 6.95 & 14.22 & 6.22 & 33.56 & na & na & 17.17 & 1.36 & na & 2.68 \\
\hline na & 1.17 & 0.93 & 2.48 & 1.71 & 1.21 & 1.57 & 2.79 & 1.39 & 5.39 & $\mathrm{na}$ & na & 2.09 & 1.55 & na & 0.73 \\
\hline na & 0.45 & 0.58 & 0.63 & 1.11 & 0.50 & 0.64 & 0.77 & 0.48 & 1.68 & na & na & 1.99 & 0.08 & na & 0.24 \\
\hline na & 0.18 & 0.10 & 0.44 & 0.14 & 0.19 & 0.26 & 0.46 & 0.22 & 0.65 & na & na & 4.62 & 0.57 & na & 0.11 \\
\hline na & 0.73 & 0.83 & 1.27 & 0.24 & 0.83 & 1.04 & 1.44 & 0.86 & 1.28 & na & na & 0.71 & 0.10 & na & 0.62 \\
\hline na & 0.126 & 0.174 & 0.211 & 0.043 & 0.138 & 0.184 & 0.240 & 0.14 & 0.214 & na & na & 4.451 & $<0,36$ & na & 0.10 \\
\hline na & 4.4 & 3.1 & 1.0 & $<1.1$ & 0.7 & 1.9 & 0.8 & 1.9 & $<1.0$ & na & na & $<0.9$ & 1.0 & na & 71 \\
\hline na & 6.21 & 3.35 & 0.24 & 0.48 & 0.60 & 2.05 & 0.32 & 2.11 & 0.15 & na & na & 0.17 & 0.12 & na & 79 \\
\hline na & 18 & 14.3 & $<4.6$ & $<4.0$ & 4 & 8 & 3.35 & 7 & $<3.2$ & na & na & 3 & 5 & na & 476 \\
\hline na & 28.6 & 14.3 & 1.8 & 0.9 & 1.6 & 5.3 & 1.86 & 8.6 & $<0.6$ & na & na & 07 & 0.4 & na & 201 \\
\hline na & 253 & 238 & 125 & 5 & 23 & 72 & 29.6 & 177 & 3 & na & na & 6 & 6 & na & 3688 \\
\hline na & 724 & 491 & 307 & 4 & 5 & 34 & 16.59 & 247 & $<6.8$ & na & na & 5 & 2 & na & 1402 \\
\hline na & 99.4 & 64.4 & 21.7 & 1.3 & 1.0 & 3.0 & 4.72 & 49.1 & 0.4 & na & na & 1.0 & 6.1 & na & 422 \\
\hline na & 5.0 & 0.4 & $<0.3$ & 0.1 & 0.1 & 0.3 & 0.34 & 0.8 & $<0.23$ & na & na & $<0.2$ & 0.4 & na & na \\
\hline
\end{tabular}

This could be a reflection of the scarcity of cumulus plagioclase or of relatively oxidising conditions during crystallisation of the rocks.

The concentrations of the noble metals are normalised to primitive mantle and plotted in order of decreasing melting temperature in Figure 8. Noble metal concentrations of the Merensky reef, and B1 and B3type Bushveld parental magmas are shown for comparison. $\mathrm{Ni}$ is included in the plots to the left of Os, and $\mathrm{Cu}$ (as well as $\mathrm{Au}$ ) to the right of Pd due to their broadly similar behaviour to Os and Pd, respectively, during fractionation. In general, the three Platreef layers on the farm Townlands show broadly similar noble metal patterns, with variation only seen in the metal contents. They are all PGE enriched when compared to the B1 and B3 parental magmas of the Bushveld Complex. The Middle Platreef has the highest PGE contents followed by the Upper Platreef, with the Lower Platreef having the lowest PGE contents. The patterns are characterised by a broadly flat pattern from $\mathrm{Ni}$ to Ir, a progressive increase from Ir to $\mathrm{Pd}$ followed by a decrease from Pd to $\mathrm{Cu}$. This is in marked contrast to the Merensky reef pattern which shows an arch-shaped mantle-normalised pattern, reflecting a strong enrichment of all PGE relative to $\mathrm{Ni}$ and $\mathrm{Cu}$ and a $\mathrm{Pt}$ peak reflecting high $\mathrm{Pt} / \mathrm{Pd}$ ratios. The lack of a strong PGE enrichment over $\mathrm{Ni}$ and $\mathrm{Cu}$ in most of the Platreef may suggest that the sulphides segregated at a relatively 


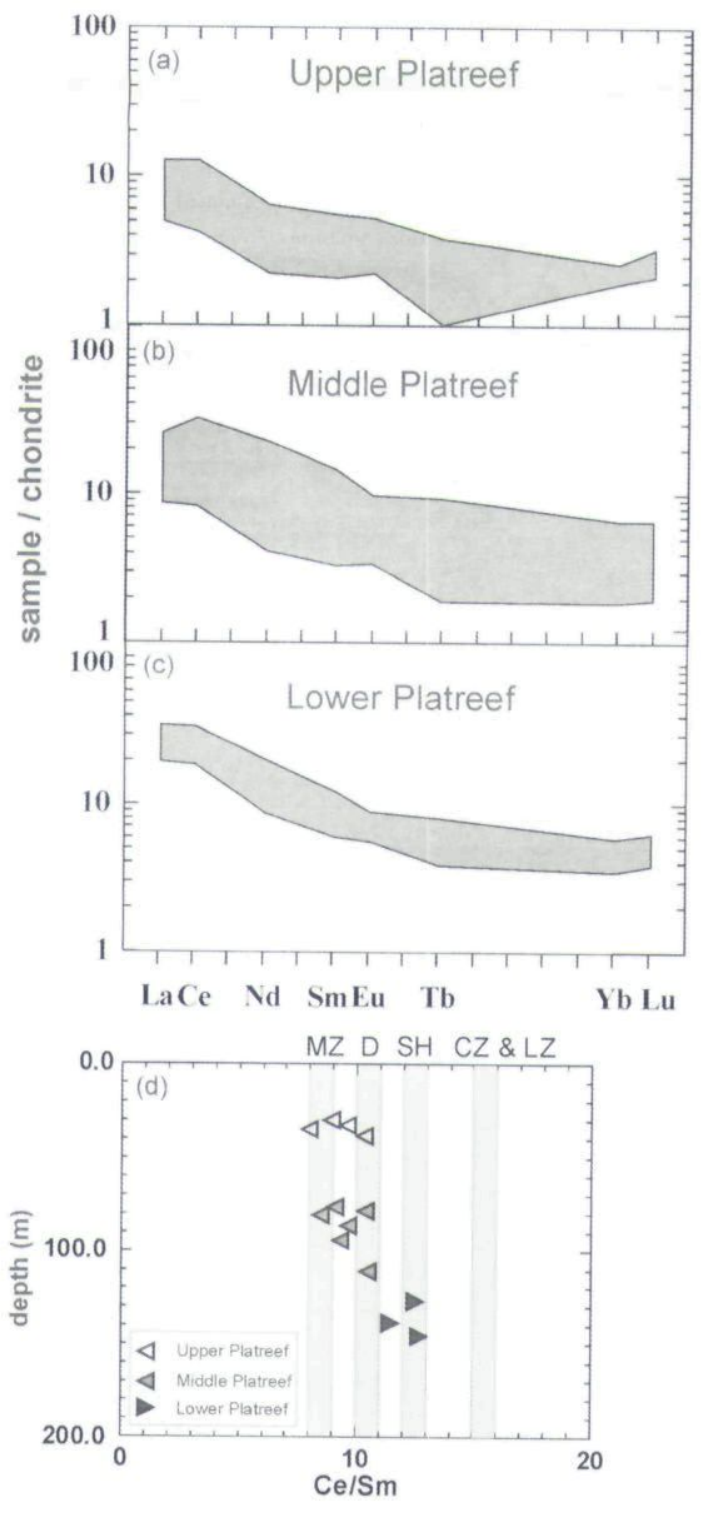

Figure 7. REE spider diagrams (chondrite normalised) from (a) Upper, (b) Middle and (c) Lower Platreef. Normalisation factors are from Taylor and McLennan (1985), (d) Ce/Sm against depth together with average ratios from Lower Zone (LZ), Critical Zone (CZ), Main Zone (MZ) (Maier and Barnes, 1998). Upper crustal shales (SH), (Taylor and McClennan, 1985) and Transvaal dolomite (D) (Klein and Beukes, 1989).

Table 4. S-isotopic analyses of samples from the Platreef and its floor rocks,

\begin{tabular}{llll}
\hline Sample & Depth $(\mathbf{m})$ & $\delta^{34} \mathbf{S}(\% \mathbf{o C D T})$ & Rock unit \\
\hline P2 & 32.69 & 5.7 & Upper Platreef \\
P3 & 34.91 & 10.1 & Upper Platreef \\
P6 & 55.8 & 6 & norite sill \\
P11 & 76.99 & 2.6 & Middle Platreef \\
P15 & 89.55 & 5.3 & Middle Platreef \\
P19 & 102.35 & 4 & Middle Platreef \\
P25 & 138.38 & 7.3 & Lower Platreef \\
P26 & 145.6 & 9.3 & Lower Platreef \\
P28 & 170.4 & 16.9 & hornfels \\
P30 & 189.95 & 14.2 & calcsilicate \\
P31 & 197.37 & 15.2 & hornfels \\
P32 & 205.18 & 15.3 & hornfels \\
\hline
\end{tabular}
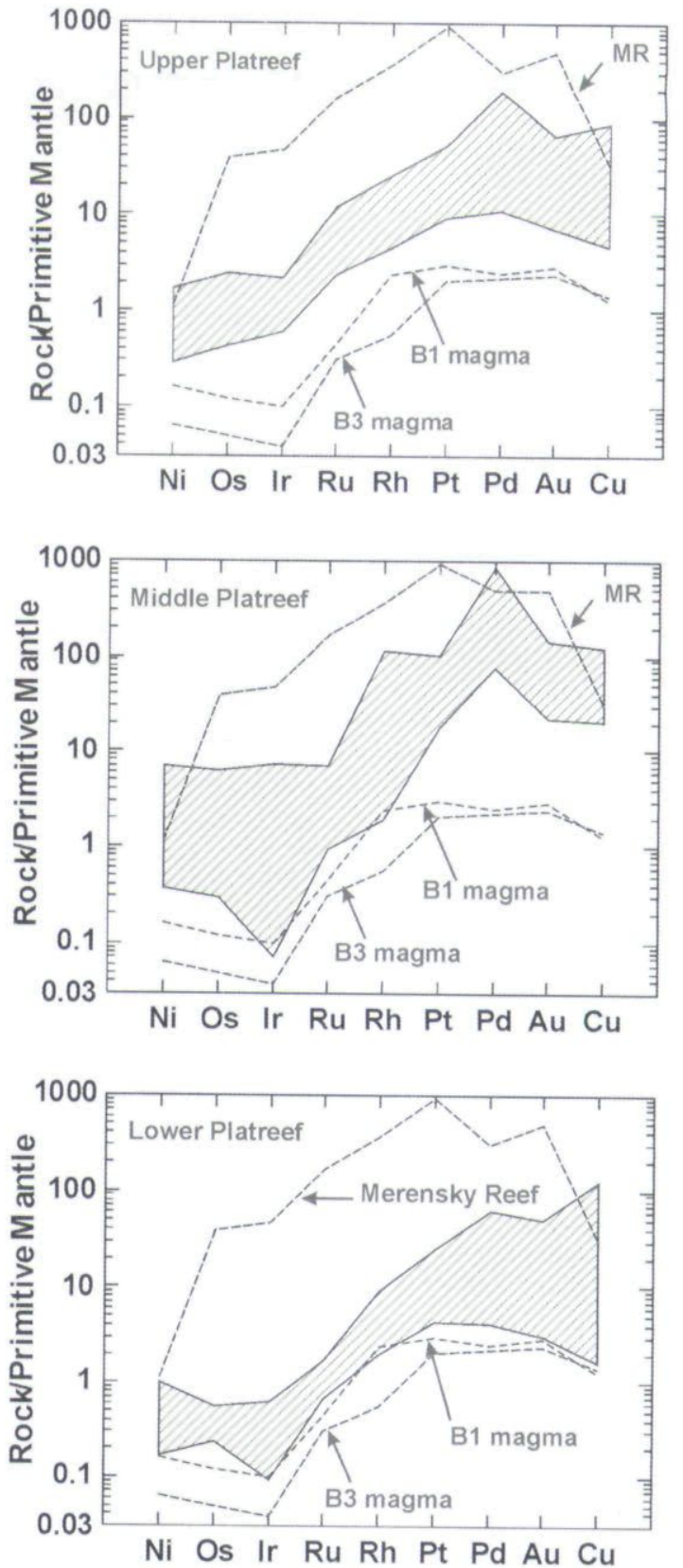

Figure 8. Mantle-normalised PGE spider diagrammes for Platreef rocks on the farm Townlands. PGE concentrations for the B1 and B3 Bushveld partental magmas are from Curls (2001) and the Merensky Reef from Barnes and Maier (2002). (Normalisation factors are from Barnes ans Maier, 1999).

lower R factor (ratio of silicate melt to sulphide melt) than those of the Merensky reef.

To assess the nature of the phases controlling the chalcophile elements, the PGE and Cu are plotted against each other in Figure 9. Pt, Pd and Ir show a fairly good positive correlation between each other (Figure 9a and b) suggesting that the PGE are essentially controlled by the same phase. The few outliers may be due to later remobilization of PGE (e.g. Armitage et al., 2002). Pd and Pt display poor correlations with Cu (Figures 9c and d). This could be the result of the lower 

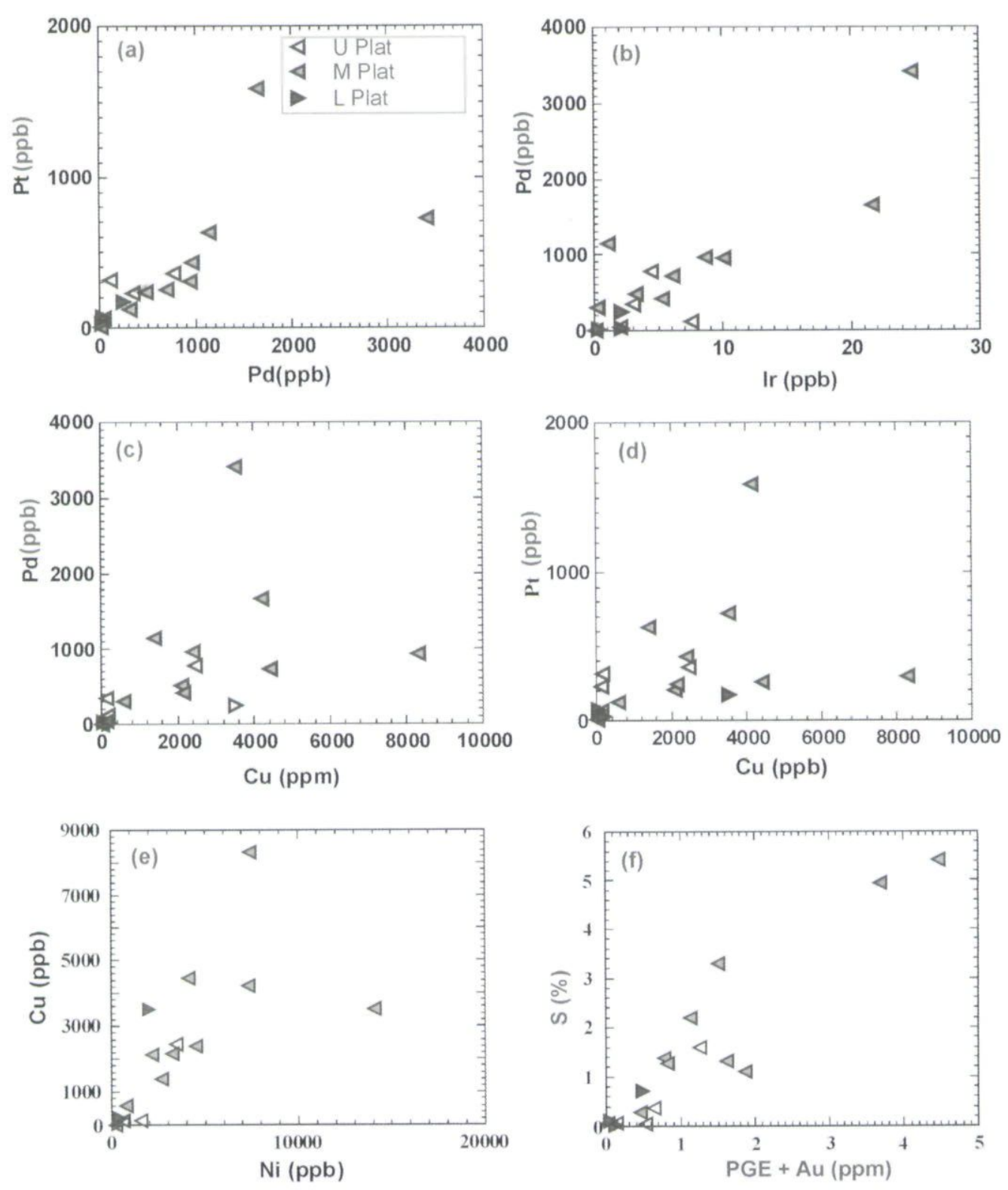

Figure 9. Binary variation diagrammes of PGE, Ni, Cu and S versus total PGE + Au. U Plat $=$ Upper Platreef, M Plat $=$ Middle Platreef, L. Plat = Lower Platreef.

D values of $\mathrm{Cu}$ relative to sulphide melt, or it may indicate some remobilization of $\mathrm{Cu}$, possibly due to late magmatic and/ or hydrothermal processes (Armitage et al., 2002).

PGE contents show fairly good positive correlations with S (Figure 9f), suggesting that sulphide was the primary metal collector. This is contrary to the situation at Sandsloot where the PGE are mostly hosted by platinum-group minerals (PGM) that are enriched in low-temperature metals and semi-metals (Armitage et al., 2002) and that were interpreted to have formed as a result of the reaction between sulphides and hydrothermal fluids.

\section{S-isotope analyses}

The available $\mathrm{S}$ isotopic data on the Platreef has been summarised by White (1994), who showed that the Platreef rocks have $\delta^{34} \mathrm{~S}$ between -3 to $+9 \%$, indicating the presence of external (crustal) $\mathrm{S}$. We provide new $\mathrm{S}$ isotopic data on 12 samples, covering the three Platreef layers and the floor rocks on the farm Townlands. This was done to i) compare the S-isotopic composition of the Platreef along strike, ii) determine the role of crustal contamination in the formation of the Platreef, and iii) determine whether the different platiniferous layers of the Platreef underwent different degrees of contamination. Analytical results are presented in Table 4.

All the Platreef samples on Townlands have positive $\delta^{34} \mathrm{~S}$ values. The highest values are found in the hornfels and the calcsilicate of the floor rocks, which have broadly similar S-isotopic signatures. The Lower Platreef 


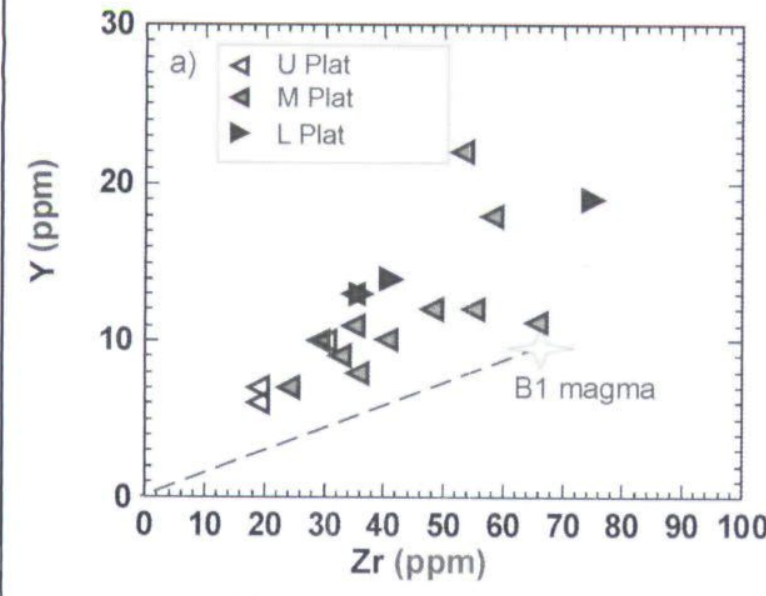

Figure 10. Plot of $\mathrm{Y}$ versus $\mathrm{Zr}$. U Plat $=$ Upper Platreef, $\mathrm{M}$ Plat $=$ Middle Platreef, L. Plat $=$ Lower Platreef. Stippled line represents back projection of B1 Bushveld parental magma (Curl, 2001).

and the Upper Platreef tend to have higher $\delta^{34} \mathrm{~S}$ than the Middle Platreef. There is also a tentative trend of an increase in the $\delta^{34} \mathrm{~S}$ values towards the base within the Middle and Lower Platreef, a phenomenon that could possibly be explained by enhanced assimilation of crustal sulphur towards the floor of each layer, perhaps by means of continued degassing of the floor rocks during crystallisation of the Platreef.

\section{Discussion and conclusions}

\section{Litbophile major and trace element data}

The mineral- and whole rock data show distinct compositional breaks between the different Platreef layers (e.g. Figure 3c). This suggests that the Platreef layers are separated by hornfels interlayers rather than xenoliths, and that the intrusives represent distinct silllike bodies rather than a single body. If the Platreef rocks represent sills, then these sills clearly do not represent melt compositions, as they have too high $\mathrm{MgO}, \mathrm{Cr}, \mathrm{PGE}$ and $\mathrm{S}$ contents (see Table 3), and differentiated rocks such as diorites are absent. For example, Bushveld B1 magma has about 12 weight $\% \mathrm{MgO}, 12 \mathrm{ppb} \mathrm{Pd}, 0.13$ weight $\% \mathrm{Cr}_{2} \mathrm{O}_{3}$ and 900 ppm S (Harmer and Sharpe, 1985, Davies and Tredoux, 1985). As a possible explanation, we suggest that the Platreef sills injected as pyroxene- and sulphide charged cumulus mushes rather than melt or the melt fraction could have been squeezed out.

The present data reveal a reversed differentiation trend within the Platreef, with progressively more primitive rocks, enriched in $\mathrm{Cr}$ and $\mathrm{MgO}$ and depleted in incompatible trace elements, being found towards the top. Based on comparison to other intrusions where the basal rocks are also relatively evolved and have elevated concentrations of incompatible trace elements (e.g. Muskox, Barnes and Francis, 1995), this may suggest enhanced contamination of the initial magma influxes. Alternatively, the relatively elevated concentration of the incompatible trace elements may indicate a relatively larger proportion of trapped melt. This proposition cannot explain the observed trace element variation. Bushveld B1 magma has $10 \mathrm{ppm} \mathrm{Y,}$ $66 \mathrm{ppm} \mathrm{Zr}$ and $29 \mathrm{ppm} \mathrm{Rb}$ (Curl, 2001). The Platreef rocks would require between 20 and 100 weight \% trapped melt to satisfy the mass balance which is unrealistic. Further, $\mathrm{Y} / \mathrm{Zr}$ ratios of Platreef rocks are markedly higher than those in B1 Bushveld magma (Figure 10). This implies that the Platreef rocks contain a significantly larger component of crust than the B1 magma. $\mathrm{Ce} / \mathrm{Sm}$ ratios of the Platreef rocks show more similarity to Main Zone cumulates than CZ cumulates which may be an indication for a genetic relationship between the Platreef magma and Main Zone magma as also suggested by McDonald and Armitage (2003). Their argument was based on the similarity in $\mathrm{Pt} / \mathrm{Pd}$ ratio between the Platreef and the Main Zone. However, $\mathrm{Pt} / \mathrm{Pd}$ ratios in the Bushveld Complex can significantly digress from primary magmatic values, e.g. some chromitites have $\mathrm{Pt} / \mathrm{Pd}$ ratios up to 100 (unpublished data of Maier), suggesting that the application of $\mathrm{Pt} / \mathrm{Pd}$ ratios to determine magmatic lineage can be problematic. $\mathrm{Ce} / \mathrm{Sm}$ ratios of the Platreef rocks also need to be interpreted with caution. If the Platreef magma was significantly contaminated with upper crustal rocks, then it is to be expected that this process would have affected ratios of the REE. Thus, our data cannot constrain unequivocally whether the Platreef is of $\mathrm{MZ}$ or $\mathrm{CZ}$ lineage.

S-isotopic analyses may be used as tracers to constrain the nature of the contaminant(s). The mantle is taken to have a $\delta^{3 i} \mathrm{~S}$ value of $\sim 0 \pm 3 \%$ and any substantial deviation from these values is interpreted to be due to assimilation of country rock sulphur with $\delta^{34} \mathrm{~S}$ values that differ from the mantle values (Ripley, 1999). The high $\delta^{34} \mathrm{~S}$ values of Platreef sulphides indicate addition of ${ }^{34} \mathrm{~S}$-enriched crustal sulphur. This confirms that the Platreef has assimilated country rock material which is thought to be important in the formation of magmatic sulphides (Naldrett, 1989). Most magmatic sulphide ores (e.g. at Kambalda, Voisey's Bay, Noril'sk, Pechenga) are thought to have formed by assimilation of external $\mathrm{S}$ from the country rocks. A similar model has been proposed by Buchanan et al. (1981) for the Platreef on the farm Tweefontein. The authors reported $\delta^{34} \mathrm{~S}$ values of 6.3 to $9.2 \%$, comparable to the $\delta^{34} \mathrm{~S}$ isotopic signatures for the Platreef on the farm Townlands.

The high $\delta^{34} \mathrm{~S}$ values of the analysed hornfels are of note. Buchanan et al. (1981) report $\delta^{34} \mathrm{~S}$ values of -11.6 to $+7.8 \%$ for the Pretoria Group shales, and Cameron (1982) reports mostly significantly negative $\delta^{34} \mathrm{~S}$ values for the Transvaal metasediments from the Timeball Hill Formation south of Johannesburg. This could indicate significant localised variation in the $\mathrm{S}$ isotopic signatures of the Transvaal Supergroup, or it may reflect fractionation of S-isotopes in the shales in the Northern 
limb due to the intrusion of the Platreef and associated devolatisation (loss of light S). Further work, including more $\mathrm{S}$ isotope analyses of the floor rocks along strike is clearly necessary to constrain this question. The analyses of calcsilicate interpreted to represent interlayers in the Pretoria Supergroup gave a $\delta^{34} \mathrm{~S}$ value of $14.2 \%$ which is heavier than the Malmani dolomite analysed by Buchanan et al., $1981\left(\delta^{34} \mathrm{~S} 7.1 \%\right)$. The hornfels and calcsilicates of the Silverton Formation probably formed in shallow water depths of between 30 and $100 \mathrm{~m}$ (Eriksson and Reczko, 1998) i.e. in slightly oxidising conditions that could explain the elevated $\delta^{34} \mathrm{~S}$ values.

\section{Platinum-Group Elements}

The present study has established a strong positive correlation between the individual PGE, and between the PGE and S, suggesting that the PGE are largely controlled by sulphides. This result may have important implications for the origin of the PGE mineralisation elsewhere in the northern limb of the Bushveld Complex. At Sandsloot mine, sulphides appear to be less common than at Townlands and the PGE appear to be largely controlled by PGM (Armitage et al., 2002). We suggest that the mineralisation at both localities (Townlands and Sandsloot) originally formed in a similar manner (concentration of PGE by segregating sulphide melt), but that at Sandsloot, much of the $\mathrm{S}$ was subsequently lost due to interaction of the magma/rock with the floor rocks. Detailed trace element data are required from Sandsloot to verify this model.

Of note are the low $\mathrm{Pt} / \mathrm{Pd}$ ratios in the Platreef at Townlands $(<1)$ and elsewhere in the northern limb relative to sulphides and rocks elsewhere in the Bushveld Complex (Pt/Pd 1.8 to 2.9, Maier and Barnes, 1999). The reef-type deposits in the Rustenburg Layered Suite (RLS) have Pt/Pd generally between 1 and 10, and the $\mathrm{B} 1$ to $\mathrm{B} 3$ parental magmas have $\mathrm{Pt} / \mathrm{Pd}$ of 1.2 . Several models have been proposed for $\mathrm{Pt} / \mathrm{Pd}$ fractionation in natural magmas and ores: (i) Pt may fractionate from Pd during differentiation of magmas. In the RLS, Pt/Pd ratios increase with height up to the Merensky reef. Sulphides associated with the base of the Complex have low $\mathrm{Pt} / \mathrm{Pd}$ ratios. Possibly, D values of $\mathrm{Pd}$ with regard to sulphide melt are somewhat higher than those of Pt, and early forming sulphides extract more Pd than Pt (Barnes and Maier, 1999). (ii) Concentration of Pd by means of hydrothermal mechanisms. This possibility is supported by the correlation between low $\mathrm{Pt} / \mathrm{Pd}$ and low $\mathrm{Ni} / \mathrm{Cu}$ ratios for the Middle Platreef (not shown). (iii) The D values of $\mathrm{Pt}$ and $\mathrm{Pd}$ could be affected by an as yet unknown factor such as volatile fugacities or elements such as Sb, As and Te, which probably occur at different concentration levels in the magmas from which the Platreef and Merensky ores crystallised.

\section{Acknowledgements}

Funding for this study was provided by the Centre for Research on Magmatic Ore Deposits (University of Pretoria). The PGE analyses were funded by a grant from the Ernest Oppenheimer Memorial Trust. Falconbridge Ventures of Africa and Thabex Exploration Company provided the core material and gave permission to publish the results. P. Sibiya and M. Claassen (University of Pretoria) are thanked for thin section preparation, S. Bramdeo (Rhodes University) for her help during microprobe analysis, M. Loubscher (University of Pretoria) for assistance with the XRF analysis, E.M. Ripley (University of Indiana) for performing the S-isotope analysis, and Patrice Gingras (University of Quebec) for the PGE analyses. The manuscript benefited from reviews by E.S Cheney and $\mathrm{C}$ Hatton.

\section{References:}

Armitage, P.E.B., McDonald, I., Edwards, J.S. and Manby, G.M. (2002). Platinum-group element mineralisation in the Platreef and calc-silicate footwall at Sandsloot, Potgietersrus District, South Africa. Transactions of the Institute of Mining and Metallurgy, 111 (reprinted from Applied Earth Science, January-April 2002), B36-45.

Barnes, S.-J. and Francis, D. (1995). The distribution of platinum-group elements, nickel, copper, and gold in the Muskox Layered Intrusion, northwest territories, Canada. Economic Geology, 90, 135-154.

Barnes, S.-J. and Maier, W.D. (1999). The fractionation of Ni, Cu and the noble metals in silicate and sulphide liquids. In: Keays, R.R., Lesher, C.M., Lightfoot, P.C. and Farrow, C.E.G. (Editors.), Dynamic processes in magmatic ore deposits and their application to mineral exploration. Geological Association of Canada, Short Course Notes 13, 69-106.

Barnes, S.-J. and Maier, W.D. (2002). Platinum-group Elements and Microstructures of Normal Merensky Reef from Impala Platinum Mines, Bushveld Complex. Journal of Petrology, 43, 103-128.

Barton, J.M., Cawthorn, R.G. and White, J. (1986). The role of contamination in the evolution of the Platreef of the Bushveld Complex. Economic Geology, 81, 1096-1104.

Bédard, L.P. and Barnes, S.-J. (2002). A comparison of the capacity of FA-ICPMS and FA-INAA to determine platinum-group elements and gold in geological samples. Journal of Radioanalytical and Nuclear Chemistry, 254, 319-329

Bennett, H. and Oliver, G. (1992). XRF analysis of Ceramics, Minerals and Applied Materials. John Wiley and Sons, New York and Brisbane, 67-93.

Buchanan, D.L., Nolan, J., Suddaby., Rouse, M.J. and Davenport, J.W.J. (1981). The genesis of sulphide mineralisation in a portion of the Potgietersrus limb of the Bushveld Complex. Economic Geology, 76. $568-579$.

Cameron, E.N. (1982), The Upper Critical Zone of the Eastern Bushveld Complex - Precursor of the Merensky Reef. Economic Geology, 77, 1307-1327.

Cawthorn, R.G., Barton, J.M., Jr. and Viljoen, M.J. (1985). Interaction of floor rocks with the Platreef on Overysel, Potgietersrus, northern Transvaal: Economic Geology, 80, 988-1006.

Curl, E.A. (2001). Parental magmas of the Bushveld Complex, South Africa. Unpublished PhD. Thesis, Department of Earth Sciences, Monash University, Australia, 140 pp.

Davies, G. and Tredoux, M. (1985). The platinum-group element and gold contents of the marginal rocks and sills of the Bushveld complex. Economic Geology, 80, 838-848.

de Waal, S.A. (1977). Carbon dioxide and water from metamorphic reactions as agents for sulphide and spinel precipitation in mafic magmas. Transactions of the Geological Society of Soutb Africa, 80, 193-196.

Eales, H.V. and Cawthorn, R.G.C. (1996). The Bushveld Complex. In: Cawthorn R.G. (Editor) Layered Intrusions, Elsevier, Amsterdam, the Netherlands, 181-228.

Eriksson, P.G. and Reczko, B.F.F. (1998). Contourites associated with pelagic mudrocks and distal delta-fed turbidites in the Lower Proterozoic Timeball Hill Formation epiric basin (Transvaal Supergroup), South Africa. Sedimentary Geology, 120, 319-335.

Harris, C. and Chaumba, J.B. (2001). Crustal contamination and fluid-rock interaction during the formation of the Platreef, northern limb of the 
Bushveld Complex, South Africa. Journal of Petrology, 42, 1321-1347. Harmer, R.E. and Sharpe, M.R. (1985). Field relations and strontium isotope systematics of the marginal rocks of the eastern Bushveld Complex. Economic Geology, 80, $813-837$.

Haughton, D.R., Roeder, P.L.. Skinner, B.J., 1974. Solubility of sulphur in mafic magmas. Economic. Geology, 69, 451- 467.

Klein, C. and Beukes, N.J. (1989). Geochemistry and sedimentology of facies transition from limestone to iron-formation deposition in the early Proterozoic Transvaal Supergroup. South Africa. Economic Geology, 84. 1741 .

Lachenicht, K. (2003). Investigation into the nature and origin of the "Hybrid norite" at Zwartfontein South Pit, Potgietersrust Platinum Limited, northern Bushveld Complex. Unpublished Honours thesis, University of Pretoria South Africa, $38 \mathrm{pp}$

Lee, C.A. (1996). A review of mineralisation in the Bushveld Complex and some other layered mafic intrusions. In: Cawthorn, R.G. (Editor) Layered Intrusions. Elsevier, Amsterdam, the Netherlands, 103-145.

Maier, W.D. (2002). Concentrations of the PGE in the Platreef on the farm Townlands, northern Bushveld Complex. 9th International Platinum Symposium, Billings, USA

Maier, W.D. and Barnes, S.-J. (1998). Concentrations of rare earth elements in silicate rocks of the Lower. Critical and Main Zones of the Bushveld Complex. Chemical Geology, 150, 85-103

Maier, W.D. and Barnes, S.-J. (1999), Platinum-Group Elements in silicate rocks of the Lower, Critical and Main Zones at Union Section, Western Bushveld Complex. Journal of Petrology, 40, 11, 85-103.

Maier, W.D. and Eales, H.V. (1997). Correlation within the UG2-Merensky Reef interval of the Western Bushveld Complex, based on geochemical. mineralogical and petrological data. Bulletin of the Geological Survey of South Africa, 120, $56 \mathrm{pp}$

McDonald, I., and Armitage, P.E.B. (2003). The Platreef of the Northern Bushveld, South Africa - is it equivalent to the Merensky Reef? Transactions of the Institute of Mining and Metallurgy, 112, no, 2 (reprinted from Applied Earth Science, August 2003), B212-213.

Mitchell, A.A. (1990). The stratigraphy, petrology and mineralogy of the Main Zone of the northwestern Bushveld Complex. South African fournal of Geology, 93, 818-831.

Manyeruke, T.D. (2003). The petrography and geochemistry of the Platreef on the farm Townlands, near Potgietersrus, northern Bushveld Complex. Unpublished MSc thesis, University of Pretoria, South Africa, $107 \mathrm{pp}$

Naldrett, A.J. (1989). Magmatic sulphide deposits. Oxford Liniversity Press. U.K., 186 pp.

Ripley, E.M. (1999). Systematics of sulphur and oxygen isotopes in mafic igneous rocks and related Cu-Ni-PGE mineralisation. In: Keays, R.R. Lesher, C.M., Lightfoot, P.C. and Farrow, C.E.G (Editors) Dynamic processes in magmatic ore deposits and their application in mineral exploration, Geological Association of Canada, Short Course, 13, 133-158. SA Mining, September, 2004. The North will rival the East. p. 34.

Sharpe, M.R., Crouse, S.P., Gain, S.B., Chunnett, G.K. and Lee, C.A. (2002) Sheba's Ridge, An unconventional setting for Platreef, UG2 and Merenskystyle PGE-BMS deposits in the Bushveld Complex. Edited by A. Boudreau. 9th International Platinum Symposium, Extended Abstracts, 407-408.

Simpkin, T. and Smith, J.V. (1970). Minor-element distribution in olivines. Journal of Geology, 78, 304-325.

Taylor, S.R. and Mclennan, S.M. (1985). The Continental Crust Its Composition and Evolution. Blackwell Scientific, U.K., 312 pp.

Van der Merwe, M.J. (1976). The layered sequence of the Potgietersrus limb of the Bushveld Complex. Economic Geology, 71, 1337-1351.

Vermaak, C.F. (1995). The platinum-group metals, A global perspective. First edition. Mintek, South Africa, 19 pp.

Viljoen, M.J. and Schurmann, L.W. (1998). Platinum-group metals. In: Wilson. M.G.C. and Anhaeusser, C.R (Editors) The Mineral Resources of South Africa, Council for Geoscience, South Africa, 532-568.

Wagner, A. (1929). The Platinum Deposits and Mines of South Africa. Oliver and Boyd, 366p.

Watson, J. S. (1996). Fast, Simple Method of Powder Pellet Preparation for X-Ray Fluorescence Analysis, X-Ray Spectrometry 25, 173-174.

White, J.A. (1994). The Potgietersrus project geology and exploration history: Proceedings, 15th CMMI Congress, S.A. Institute of mining and Metallurgy, 173-182.

Wilson, A.H., Lee, C.A and Brown, R.T. (1999). Geochemistry of the Merensky reef, Rustenburg Section. Bushveld Complex: controls on silicate framework and distribution of trace elements. Mineralium Deposita, 34. 657-672. www panpaladium.au

Editorial handling: J. M. Barton 
Copyright of South African Journal of Geology is the property of Geological Society of South Africa and its content may not be copied or emailed to multiple sites or posted to a listserv without the copyright holder's express written permission. However, users may print, download, or email articles for individual use. 